\title{
UNCLASSIFIED STEREA
}

ORNL-1716

This document consists of 31 pages.

Copy 2 toof 265 copies. Series A. 250

Contract No. W-7405-eng-26

ANP DIVISION

TURBULENT HEAT TRANSFER FROM A MOLTEN FLUORIDE SALT

MIXTURE TO SODIUM-POTASSIUM ALLOY IN A

DOUBLE-TUBE HEAT EXCHANGER

D. F. Salmon

DATE ISSUED

NOV 31954

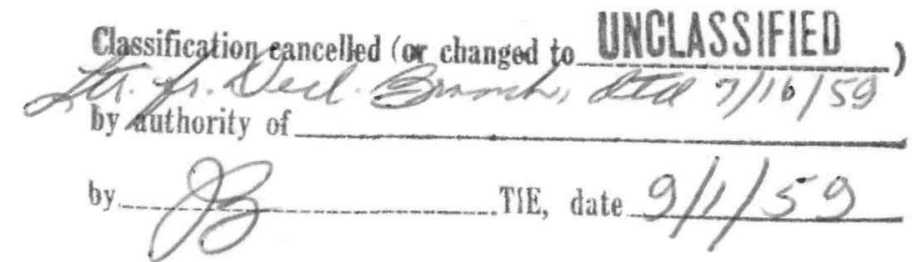

OAK RIDGE NATIONAL LABORATORY

Operated by

CARBIDE AND CARBON CHEMICALS COMPANY

A Division of Union Carbide and Carbon Corporation

Post Office Box P

Oak Ridge, Tennessee

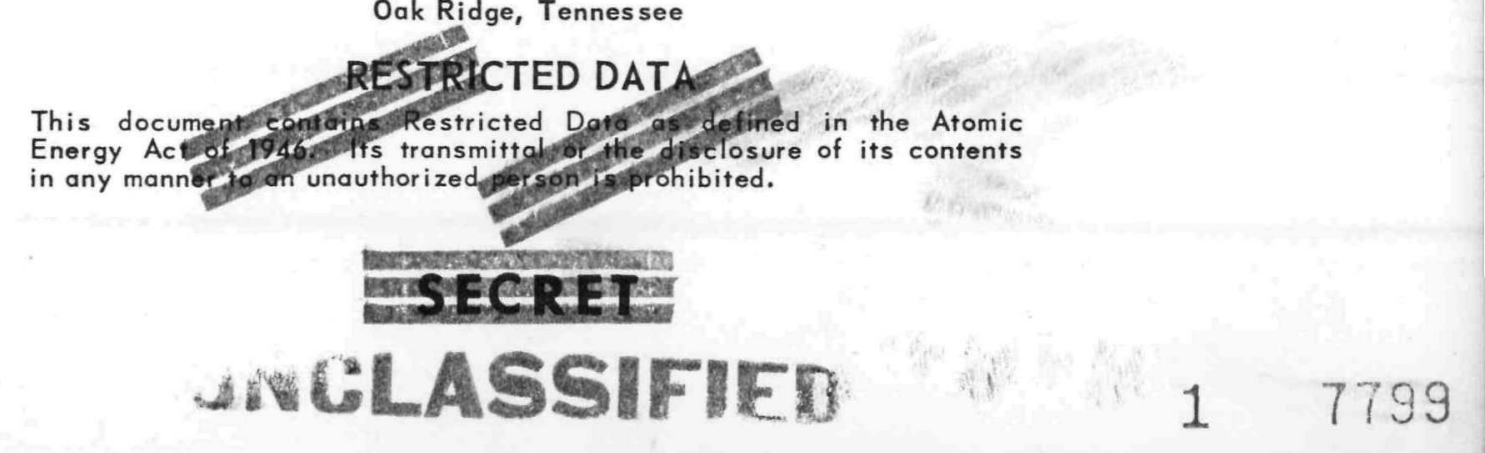




\section{DISCLAIMER}

This report was prepared as an account of work sponsored by an agency of the United States Government. Neither the United States Government nor any agency Thereof, nor any of their employees, makes any warranty, express or implied, or assumes any legal liability or responsibility for the accuracy, completeness, or usefulness of any information, apparatus, product, or process disclosed, or represents that its use would not infringe privately owned rights. Reference herein to any specific commercial product, process, or service by trade name, trademark, manufacturer, or otherwise does not necessarily constitute or imply its endorsement, recommendation, or favoring by the United States Government or any agency thereof. The views and opinions of authors expressed herein do not necessarily state or reflect those of the United States Government or any agency thereof. 


\section{DISCLAIMER}

Portions of this document may be illegible in electronic image products. Images are produced from the best available original document. 
1. G. M. Adamson

2. R. G. Affel

3. J. F. Bailey (consultant)

4. C. R. Baldock

5. C. J. Barton

6. E. S. Bettis

7. D. S. Billington

8. F. F. Blankenship

9. E. P. Blizard

10. M. A. Bredig

11. F. R. Bruce

12. A. D. Callihan

13. D. W. Cardwell

14. C. E. Center

15. R. A. Charpie

16. G. H. Clewett

17. C. E. Clifford

18. W. B. Cottrell

19. R. G. Cochran

20. D. D. Cowen

21. F. L. Culler

22. L. B. Emlet (K-25)

23. W. K. Ergen

24. A. P. Froas

25. W. R. Grimes

26. A. G. Grindell

27. D. C. Hamilton

28. E. E. Hoffman

29. H. W. Hoffman

30. A. Hollaender

31. A. S. Householder

32. J. T. Howe

33. R. W. Johnson

34. W. H. Jordan

35. G. W. Keilholiz

36. C. P. Keim

37. M. T. Kelley

38. F. Kertesz

39. E. M. King

40. J. A. Lane

41. C. E. Larson

42. R. S. Livingston

43. R. N. Lyon

44. W. D. Manly

45. L. A. Mann
46. W. B. McDonald

47. J. L. Meem

48. A. J. Miller

49. K. Z. Morgan

50. E. J. Murphy

51. J. P. Murray $(Y-12)$

52. G.J. Nessle

53. P. Patriarca

54. H. F. Poppendiek

55. P. M. Reyling

56. D. F. Salmon

57. H. W. Savage

58. A. W. Savolainen

59. E. D. Shipley

60. O. Sisman

61. M. J. Skinner

62. G. P. Smith

63. L. P. Smith (consultant)

64. A. H. Snell

65. W. K. Stair (consultant)

66. C. L. Storrs

67. C. D. Susano

68. J. A. Swartout

69. E. H. Taylor

70. J. B. Trice

71. E. R. Van Artsdalen

72. F. C. VonderLage

73. J. M. Warde

74. A. M. Weinberg

75. J.C. White

76. G. D. Whitman

77. E. P. Wigner (consultant)

78. G. C. Williams

79. J. C. Wilson

80. C. E. Winters

81-90. ANP Library

91. Biology Library

92-96. Laboratory Records Dept.

97. Laboratory Records, ORNL RC

98. Health Physics Library

99. Metallurgy Library

100. Reactor Experimental Engineering Library

101-103. Central Research Library 
104. Air Force Engineering Office, Oak Ridge

105. Air Foree Plant Representative, Burbank

106. Air Force Plant Representative, Seattle

107. Air Force Plant Representative, Wood-Ridge

108. ANP Project Office, Fort Worth

109-120. Argonne National Laboratory (1 copy to Kermit Anderson)

121. Armed Forces Special Weapons Project, Sandia

122. Armed Forces Special Weapons Project, Washington (Gertrude Camp)

123-131. Atomic Energy Commission, Washington (Li. Col. M. J. Nielsen)

132. Battelle Memorial Institute

133-138. Brookhaven National Laboratory

139. Bureau of Aeronautics (Grant)

140. Bureau of Ships

147.148. Carbide and Carbon Chemicals Company (Y.12 Plant)

149. Chicago Patent Group

150. Chief of Naval Research

151. Commonwealth Edison Company

152. Convair, San Diego (C. H. Helms)

153. Curtiss-Wright Corporation, Wright Aeronautical Division (K. Campbell)

154. Department of the Navy - Op-362

155. Detroit Edison Company

156-160. duPont Company, Augusta

161. duPont Company, Wilmington

162. Foster Wheeler Corporation

163-165. General Electric Company, ANPD

166-170. General Electric Company, Richland

171. Glen L. Martin Company (T. F. Nagey)

172. Hanford Operations Office

173. Lowa State College

174-181. Knolls Atomic Power Laboratory

182-183. Loekland Area Office

184-185. Los Alamos Seientific Laboratory

186. Materials Laboratory (WADC) (Col. P. L. Hill)

187. Monsanto Chemical Company

188. Mound Laboratory

189-190. National Advisory Committee for Aeronautics, Cleveland (A. Silverstein)

191. National Advisory Committee for Aeronautics, Washington

192-193. Naval Research Laboratory

194. New York Operations Office

195-196. North American Aviation, Inc.

197-202. Nuclear Development Associates, Inc.

203. Patent Branch, Washington

204-210. Phillips Petroleum Company (NRTS)

211-222. Powerplant Laboratory (WADC) (A. M. Nelson)

223-232. Pratt \& Whimey Aircraft Division (Fox Project)

233-234. Rand Corporation (I copy to V. G. Henning)

235. San Francisco Field Office

236. Sylvania Electrie Products, Ine.

237. USAF Headquarters

238. U. S. Naval Radiological Defense Laboratory 
239-240. University of California Radiation Laboratory, Berkeley

241-242. University of California Radiation Laboratory, Livermore

243. Walter Kidde Nuclear Laboratories, Inc.

244-249. Westinghouse Electric Corporation

250-264. Technical Information Service, Oak Ridge

265. Division of Research and Medicine, AEC, ORO 


\section{CONTENTS}

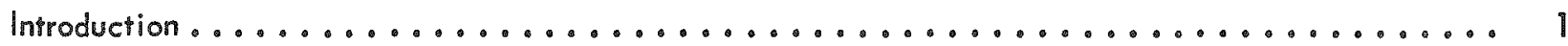

Deseription of Equipment ..................................

Test Procedure ......................................... 4

Method of Calculation ................................... 4

Correlation of Data . . . . . . . . . . . . . . . . . . . . . . . . . . . . . 6

Test Results ........................................... 7

Discussion of Results .................................... 10

Conclusions............................................... 12

Nomenclature ............................................. 13

Appendix 1. Equation for Intermediate Axial Stream Temperature with Logarithmic Distribution .... 16

Appendix 2. Derivation of Equations for Wilson Line Analysis. . . . . . . . . . . . . . . 18

Appendix 3. Physical Properties of the Fluoride Salt NaF. $\mathrm{rF}_{4}-\mathrm{UF}_{4}(50-46.4$ mole \%) and of Sodium-Potassium Eutectic Alloy ....................... 19

Appendix 4. Sample Calculation of Data Point 4 . . . . . . . . . . . . . . . . . . . . . . . 22 


\title{
TURBULENT HEAT TRANSFER FROM A MOLTEN FLUORIDE SALT MIXTURE TO SODIUM-POTASSIUM ALLOY IN A DOUBLE-TUBE HEAT EXCHANGER
}

\author{
D. F. Salmon
}

\section{INTRODUCTION}

Circulating-fuel reactor systems for high-performance, high-temperature power plants place exacting requirements on the fluids which must serve as heat transfer media. It is necessary that the fluids have good heat transfer properties, be stable chemically at an elevated temperature, have a reasonably low melting point, be compatible with container materials, and require only a minimum in pumping power. Aside from the chemical problem involved in finding materials with which the proper amount of nuclear fuel may be combined, there are the research and the experimentation required to determine whether the above- mentioned specifications are met.

Mixtures of fluoride salts were found to show promise for the circulating-fuel application. This report is concerned with an experiment to measure the heat transfer characteristics of the fluoride salt mixture $\mathrm{NaF}-\mathrm{ZrF}_{4}-\mathrm{UF}_{4}$ (50-46-4 mole \%).

The primary purpose of the experiment was to make a correlation of $\mathrm{film}$ heat transfer coefficients, and a secondary purpose was to determine the effect on heat transfer of deposits resulting from corrosion or mass transfer of container materials.

\section{DESCRIPTION OF EQUIPMENT}

A schematic diagram of the various components of the test apparatus is shown in Fig. 1.

The only pump available for the fluoride salt circuit was a type 316 stainless steel sump pump capable of delivering $10 \mathrm{gpm}$ at $40 \mathrm{ft}$ of head and $3600 \mathrm{rpm}$. This pump was designed for hightemperature application and for liquids which could not be sealed against directly at the shaft in the ordinary manner. It had a water-cooled rotary face seal for maintaining an inert gas blanket on the fluid being pumped. An automatic level control system was provided for maintaining the liquid level in the pump within prescribed limits.

The heat transfer coefficients were measured in a double-tube heat exchanger. The fluoride salt was cooled in the center tube by a countercurrent flow in the annulus of sodium-potassium alloy (hereafter referred to as NaK). The center tube of the heat exchanger, made of nickel, was $0.269 \mathrm{in}$. in inside diameter with a length-to-diameter ratio of 40 . The outer tube was $3 / 4$-in., schedule- 40 , type 316 stainless steel pipe which was rigidly connected to the center tube at one end and bellows-joined at the other end to allow for differential expansion.
Heating of the fluoride salt was accomplished in a length of 1-in., schedule-40, Inconel pipe by electrical tube furnace elements assembled on the pipe and covered with preformed insulation. The NaK stream was cooled by natural convection of air in a section of finned pipe which was ducted and provided with a damper for control.

The NaK was circulated by a conventional electromagnetic pump. The fluoride salt and the NaK flow rates were measured by water-calibrated venturi tubes; the calibrations were corrected to reflect the discharge coefficients and the differences in densities of the respective fluids. An electromagnetic flowmeter was also available for determining the NaK flow rate.

Inlet and outlet temperatures of the fluoride salt and the NaK were measured by fixed, Inconelsheathed, Chromel-Alumel probes on the center lines of the piping. An adjustable probe that was provided in the annulus of the heat exchanger could be brought in touch-contact with the outer surface of the center tube wall for temperature measurement. These probes were calibrated to $1 / 2{ }^{\circ} \mathrm{F}$ against a National Bureau of Standards 
certified platinum-platinum-rhodium thermocouple in a calibrating furnace. Thermocouple readings were taken on a Leeds and Northrup K-2 potenti- ometer, and an ice-bath cold junction was used.

Figures 2, 3, and 4 are photographs of the test equipment.

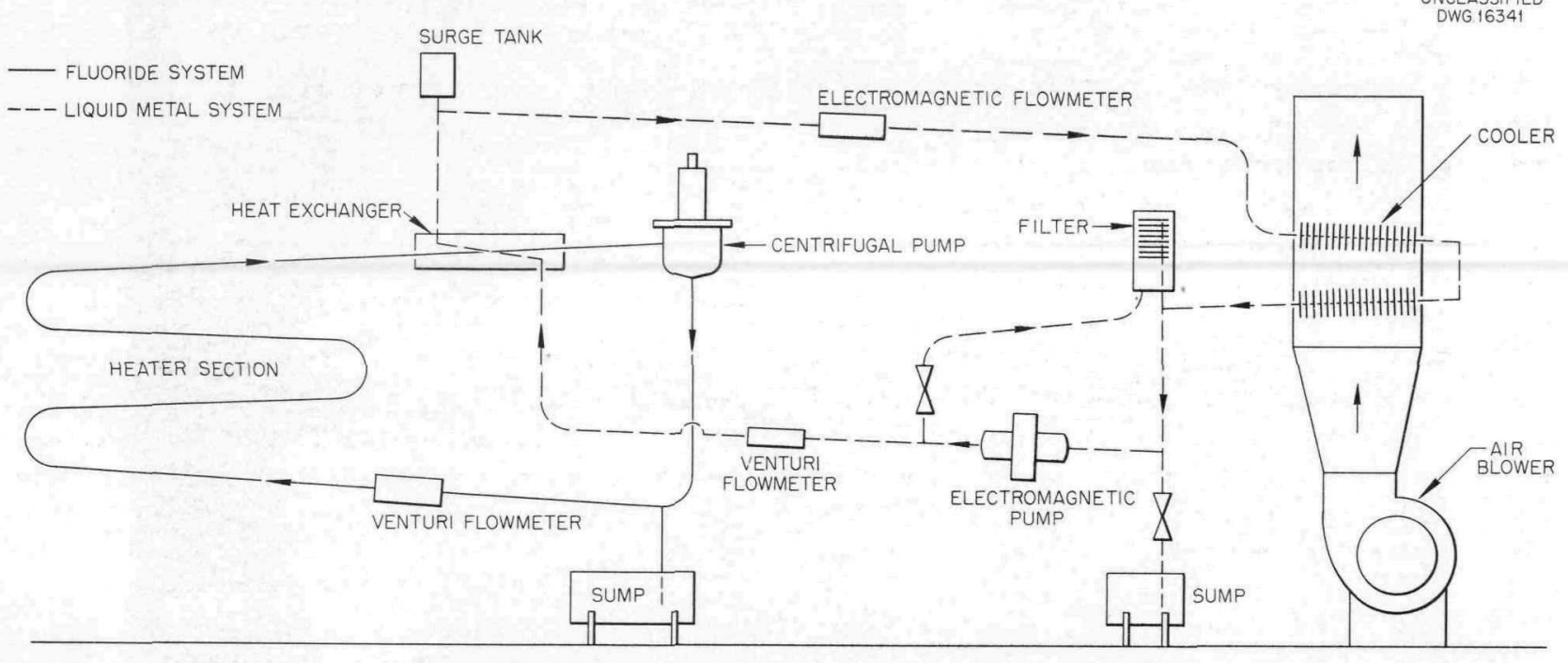

Fig. 1. Schematic Diagram of Bifluid Loop.

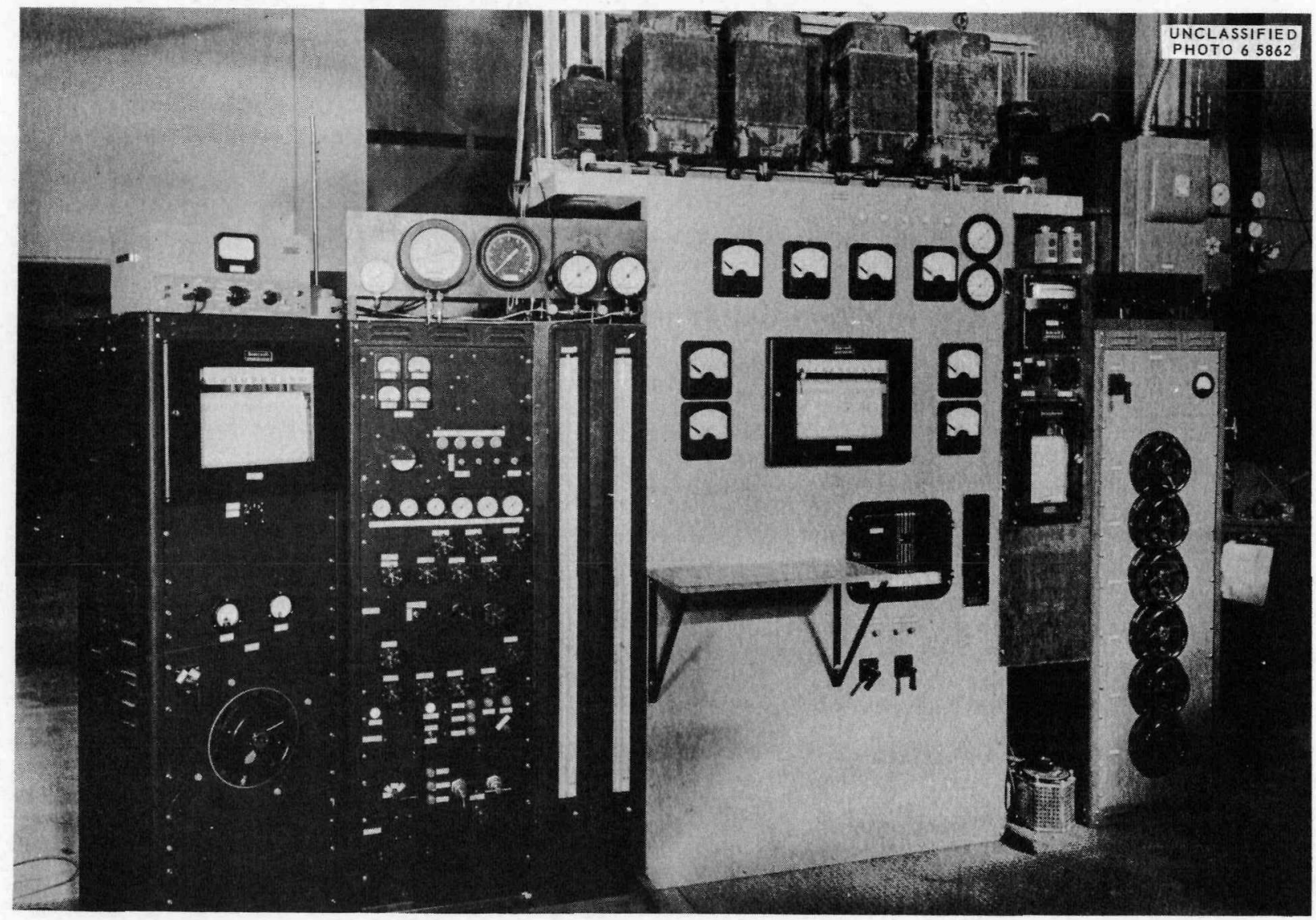

Fig. 2. Instrument and Power Panel. 


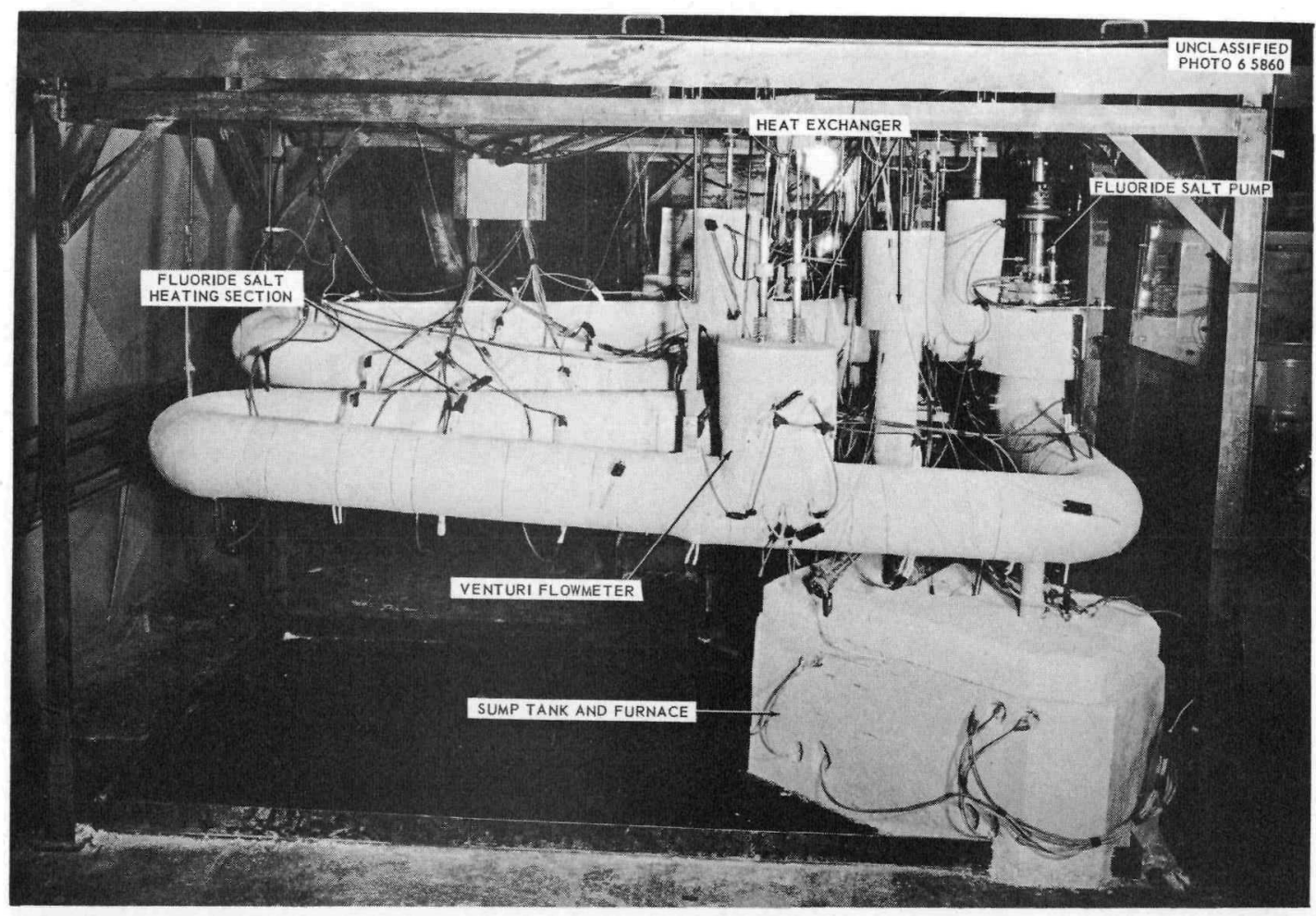

Fig. 3. Fluoride Salt Loop.

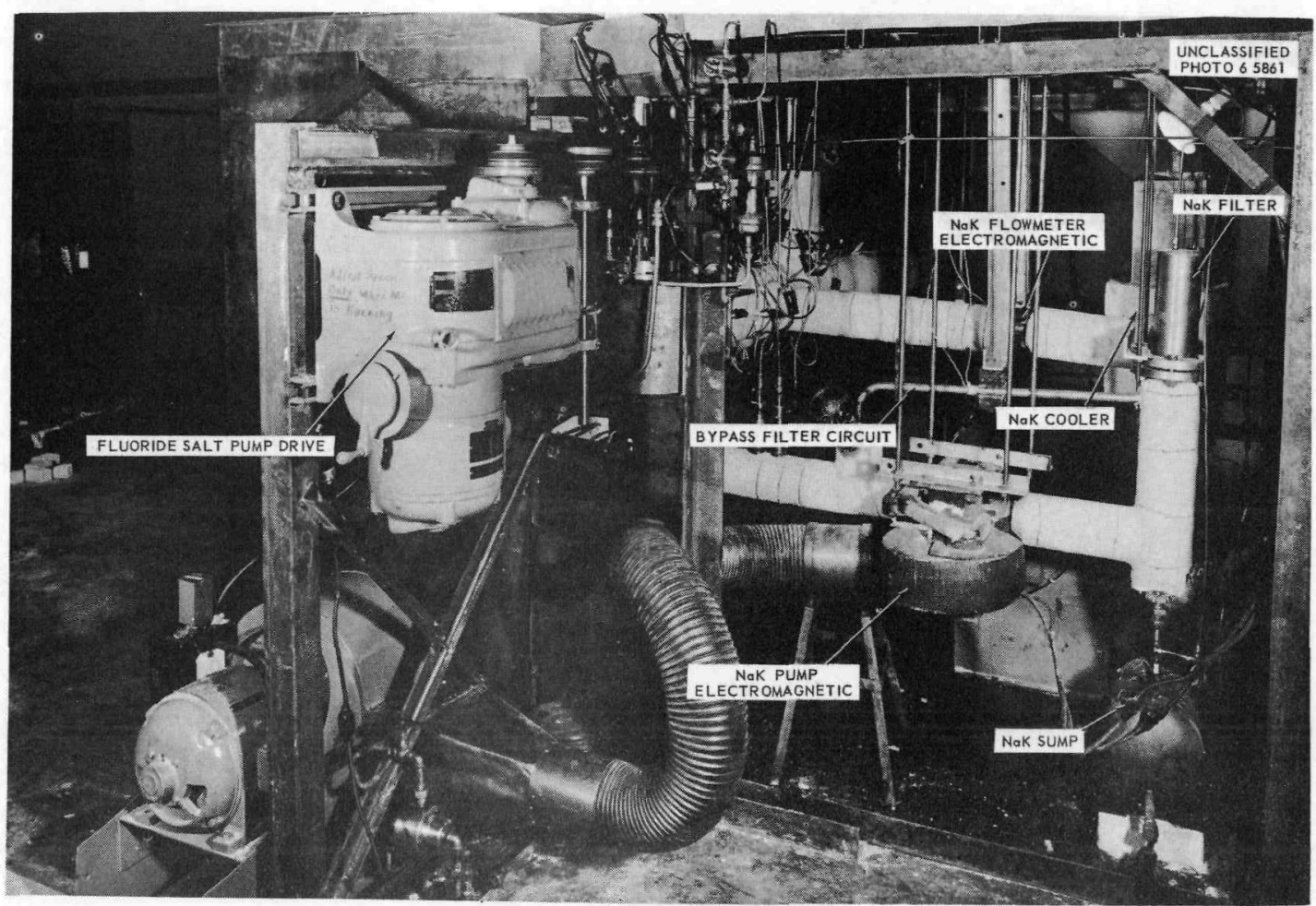

Fig. 4. NaK Loop. 


\section{TEST PROCEDURE}

The melting point of the fluoride salt was approximately $960^{\circ} \mathrm{F}, 1$ and, consequently, it was necessary at all times to maintain the walls of the fluoride salt system above this value. In fact, the walls were kept at from 50 to $100^{\circ} \mathrm{F}$ above the melting point as a precaution against freezing. For all runs, the electrical power to the fluoride

'Physical Property Charts for Some Reactor Fuels, Coolants, and Miscellaneous Material (3rd Edition), ORNL CF-53-3-261 (March 20, 1953). salt heaters was controlled to maintain a constant inlet temperature to the heat exchanger. The fluoride salt pump speed was set to give a desired flow rate, and this flow was maintained for a series of different NaK flow rates. The damper to the NaK cooling section was adjusted in each case to hasten attainment of steady-state conditions before data were recorded. Data were taken during each run at each $\mathrm{NaK}$ flow rate; a total of 80 data points was taken.

\section{METHOD OF CALCULATION}

A heat balance on the fluoride salt and NaK streams in the heat exchanger was made, initially, to serve as a check on the validity of the data and to provide the basis for calculation of the heat flux, $q / A_{0}$. The value of $q$ used for determining the heat flux was an average of that obtained by applying the first two of Eqs. 1 to the fluoride salt and NaK streams:

$$
\begin{aligned}
q & =w_{F} c_{F} \Delta t_{F}, \\
& =w_{N} c_{N} \Delta t_{N} \\
& =U_{0} A_{0} \Delta t{ }_{L M},
\end{aligned}
$$

where the subscripts $F$ and $N$ refer to the fluoride salt and the NaK, respectively. The insulation heat loss from the heat exchanger was neglected since it was, in actuality, less than $1 \%$. The overall heat transfer coefficient was calculated from the third of Eqs. 1:

$$
U_{\circ}=\frac{q / A_{o}}{\Delta t_{L M}} .
$$

The adjustable probe, located 16 diameters downstream from the fluoride inlet, provided the outer surface temperature of the center tube; from the outer surface temperature the inside surface temperature was determined by using the conduction equation

$$
t_{w F}=t_{w N}+\frac{q_{\mathrm{av}} \ln \frac{D_{o}}{D_{i}}}{2 \pi k{ }_{w}^{L}} .
$$

A logarithmic axial distribution of temperature was assumed for calculating the stream temperature opposite the measured wall temperature. Derivations of the equations for obtaining these temperatures are presented in Appendix 1. The following equations were then used to arrive at a film heat transfer coefficient:

$$
b_{F}=\frac{q_{\mathrm{av}}}{A_{i}\left[t_{F(0.4)}-t_{w F}\right]}
$$

and

$$
{ }^{b}{ }_{N}=\frac{q_{\text {ov }}}{A_{0}\left[t_{w N}-t_{N(0.4)}\right]} .
$$

An individual heat transfer coefficient may be distingui shed from the film coefficients given above in that it is obtained by separation of the over-all coefficient defined in Eq. 2. Some such separation process is always required when the difficult problem of measuring surface temperature is not attempted. In this case, the valuable graphical analysis of the over-all heat transfer coefficient attributed to Wilson by McAdams ${ }^{2}$ is useful. The analysis is based on the premise that a plot of $1 / U_{0}$ vs $1 / v^{0.8}$ will produce a straight line if one of the fluid velocities is held constant and the other is varied over a specific range of values. Wilson's method was applied to the data of this experiment as shown in Fig. 5 , where $1 / U_{0}$ is plotted against $1 / v_{N} 0.8$. The run with the greatest number of values for NaK velocity was used to

\footnotetext{
${ }^{2}$ W. H. McAdams, Heat Transmission, 2d ed., p 273, McGraw-Hill, New York, 1942.
} 
establish the slope of the lines. The lines were extrapolated to $1 / v_{N}^{0.8}=0$, which was equivalent to letting the NaK velocity approach infinity, in which case the NaK film resistance, $1 / b_{N}$ approached zero.

An individual heat transfer coefficient for the fluoride salt was then separated from the extrapolated over-all coefficient at $1 / 2{ }_{N}^{0.8}$ by using the equation (derived in Appendix 2)

(6)

$$
b_{F}=\frac{1.22}{\frac{1}{U_{\text {oo }}}-0.0000788} .
$$

By assuming the value of $b_{F}$ to be constant along each of the Wilson lines, an individual coefficient for NaK was separated form the over-all coefficient by using the following equation (derived in Appendix 2):

(7) $b_{N}=\frac{1}{\frac{1}{U_{o}}-\frac{1.22}{b_{F}}-0.0000788}$.

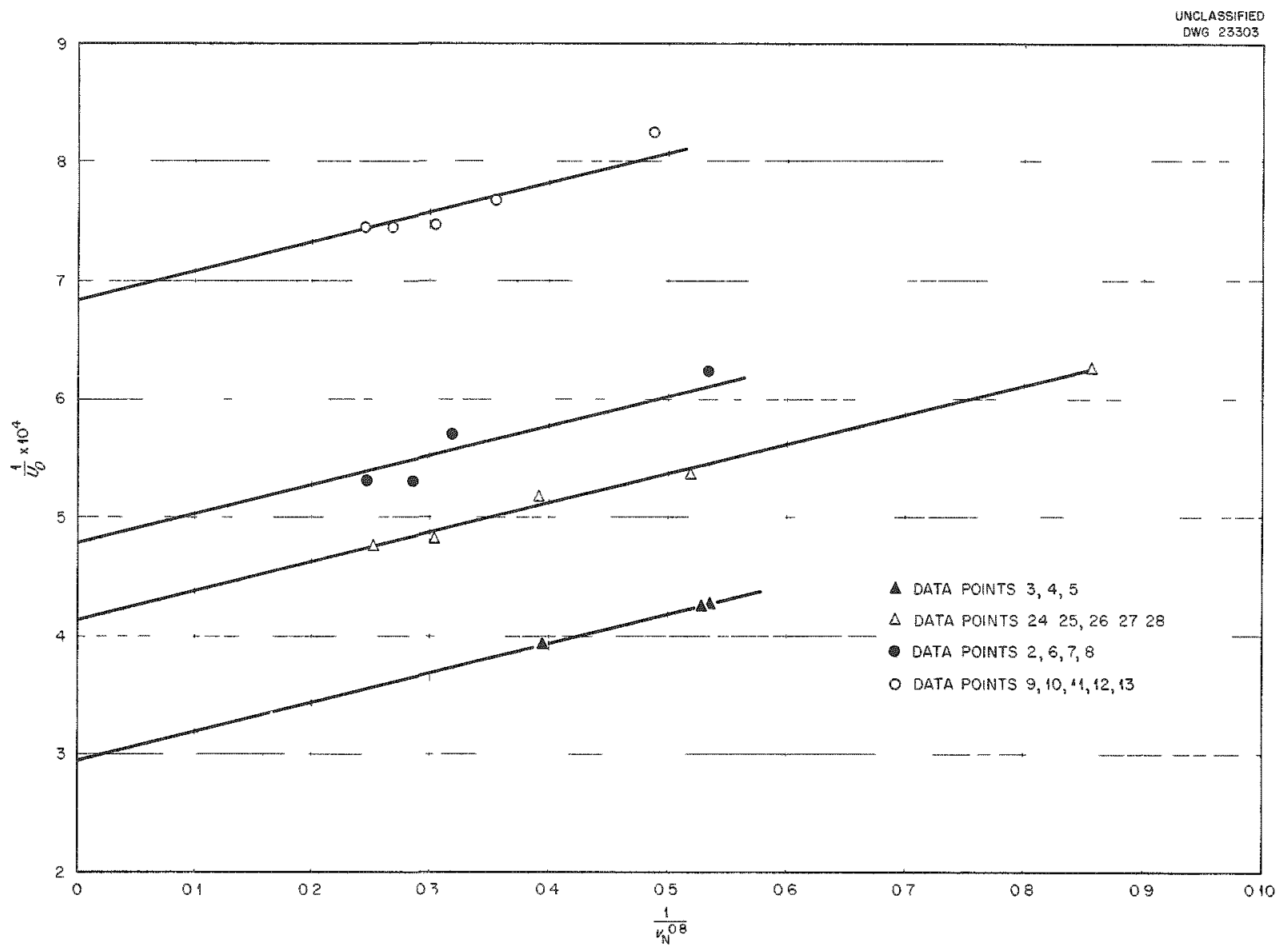

Fig. 5. Wils on Line Plot. 


\section{CORRELATION OF DATA}

Dimensional analysis of the physical properties, together with the hydrodynamic and geometric factors affecting heat transfer between a turbulently flowing fluid and a bounding surface such as a tube, gives a product function of the Nusselt, Reynolds, and Prandt l moduli. The function is usually written as

$$
\mathrm{Nu}=C \mathrm{Re}^{n} \mathrm{Pr} p \text {. }
$$

The relationships of these parameters for ordinary fluids such as warer, gases, or oils, as differentiated from liquid metals, have been empirically determined from the data of many experimental investigations. The generally accepted value for the exponent $n$ is 0.8 . However, for the constant $C$ and the exponent $p$, there is variation in the evidence; the values depend on whether the fluid is being heated or cooled, on the magnitude of the fluid viscosity, and on whether the evaluation is based on the bulk temperature of the stream or on an average of this temperature and the surface temperature.

McAdams recommends ${ }^{3}$ for fluids of high vis. cosity, that is, presumably, higher than twice that of water, the Colburn equation

$$
\mathrm{Nu}=0.023 \operatorname{Re}_{f}^{0.8 \mathrm{Pr}_{f}}{ }^{1 / 3},
$$

or that of Sieder and Tate:

$$
N_{u}=0.027\left(\frac{\mu}{\mu_{u}}\right)^{0.14} \operatorname{Re}^{0.8} \operatorname{Pr}^{1 / 3} .
$$

For these equations, the Reynolds modulus should be in excess of 10,000 . The viscosity correction term $\left(\mu / \mu_{u}\right)^{0.14}$ compensates for the variation in the temperature difference between the bulk temperature of the stream and that of the wall. In the transition range of Reynolds moduli from approximarely 2,100 to 10,000 , called by McAdams "the dip region," there is a dependency on the length-to-diameter $(L / D)$ ratio of the heat exchange surface, the amount being a function of the Reynolds modulus. Eckert ${ }^{5}$ states that the equation of Hausen,

\footnotetext{
3 lbid., p 168.

4 lbid., p 167.

${ }^{5} E_{0}$ R. G. Eckert, Introduction to the Transfer of Heat and Mass, P115, McGraw-Hill, New York, 1950.
}

(11) $\begin{aligned} & N_{u}=0.116\left(\frac{\mu}{\mu_{u}}\right)^{0.14}\left(\operatorname{Re}^{2 / 3}-125\right) \\ & \operatorname{Pr}^{1 / 3}\left[1+\left(\frac{D}{L}\right)^{2 / 3}\right] .\end{aligned}$

will satisfactorily reproduce values in the Reynolds modulus range from 2300 to 6000 . Equation 11 is also useful for the entrance region of tubes where the velocity profile has not developed fully, although the Reynolds modulus based on mean stream velocity is sufficiently high for full develop. ment.

The theoretical approach to turbulent heat trans. fer in a tube has advanced to the stage where experimental values can be predicted with very good agreement. von Kármán's postulation of three zones in the flow field, namely, the laminar sub. layer, the buffer layer, and the turbulent core, was largely responsible for the advance. Although the theoretical approach was not used in this work, reference will be made to an extension of von Kármán's theory by Boelter, Martinelli, and Jonassen (as described by Eckert ${ }^{6}$ ) and by Martinelli。 ${ }^{7}$ The extension concerns the temperature rotio $\left(t_{u}-\right.$ $t) /\left(t_{u}-t_{c}\right)$ which was determined by them and plotted as a function of Reynolds and Prandil moduli. The result gives the amount of deviation expected when center-line temperature rather than bulk temperature is used to evaluate physical properties in correlating experimental heat transfer data.

The correlations discussed above for ordinary fluids do not hold for liquid metals which have low viscosity and high thermal conductivity and thus very low Prandil moduli. Thermal conductivity is important even in the turbulent core of the stream where, for ordinary fluids, it is assumed, in the equations, that all the heat is transferred by mixing action. For heat transfer to liquid metals in a tube, Martinelli ${ }^{8}$ derived an equation which was later greatly simplified by Lyon," but there is as

\footnotetext{
6lbido, p 125.

${ }^{7}$ R. C. Mortinelli, "Heat Transfer to Molten Metals" Trans. Am. Soc. Mech. Engrs, 69, 955 (1947).

8lbida, p 947-959.

${ }^{9}$ R. N. Lyon, Forced Convection Heat Transfer Theory and Experiments with Liquid Metals, ORNL-361 (Aug. $19,1949)$.
} 
yet no abundance of data to substantiate their work.

There is no widely accepted procedure for calculating heat transfer to turbulently flowing fluids in annuli, whether they are ordinary fluids or liquid metals. The usual practice is to apply the tube equations, with an equivalent diameter substituted, and to add a correction term consisting of the ratio of annulus diameters to some power. One equation for liquid metals in annuli, corroborated in particular with NaK by Werner, King, and Tidball (described in the work of Claiborne ${ }^{10}$ ),

10H. C. Claiborne, A Review of the Literature on Heat Transfer in Annuli and Noncircular Ducts for Ordinary Fluids and Liquid Metals, ORNL. CF.52-8-166. is the following:

$$
\begin{gathered}
N u_{a n}=\left[4.9+0.0175(\operatorname{Re} \times \operatorname{Pr})^{0.8}\right] \\
\left(\frac{D_{1}}{D_{0}}\right)^{0.53} .
\end{gathered}
$$

The bracketed quantity is equal to 0.7 of Lyon's expression ${ }^{9}$ for Nusselt's modulus in a tube, and the diameter ratio correction is recommended by Monrad and Pelton, who experimented with ordinary fluids in annular spaces. The work of Monrad and Pelton is described by Claiborne ${ }^{10}$ and also by MeAdams."

\footnotetext{
11W. H. MeAdans, Heat Transmission, 2d ed., p 201, McGraw-Hill, New York, 1942.
}

\section{TEST RESULTS}

A total of 80 data points was taken during the test, but only 19 of the points were used in the analysis for this report. The remaining data were not used because of fouling that occurred on the fluoride salt side of the heat exchanger as a result of mass transfer of iron from the stainless steel pump parts. When the heat exchanger was sectioned, a layer was found which built up gradually from the hot end to a thickness of approximately $0.030 \mathrm{in}$. at the cold end. Spectrographic analysis showed the layer to be pure iron.

The basis for selecting the data points that were analyzed is indicated in Fig. 6 , where the fluoride salt system pressure drop is plotted as a function of volume flow rate. The points are compared with a theoretically calculated curve of pressure drop vs volume flow rate. The chosen points fall on the curve representing an unfouled condition, while the rejected points lie considerably above this curve. The sequence of the measurements can be traced. Instances can be seen where pressure drop increased sharply without increase in flow and, in other cases, where pressure drop remained constant while flow increased.

The data points used in the analysis and the pertinent calculated quantities are tabulated in Table 1. Physical properties of the fluoride salt and the NaK are plotted as functions of temperature in Appendix 3. A sample calculation of data point 4 is presented in Appendix 4.

The fluoride salt flow rate was varied from 1 to 5 $\mathrm{gpm}$, and the system pressure drops for these flows were, respectively, 5 to $55 \mathrm{psi}$. The Nak flow rate was varied from 1.7 to $9.25 \mathrm{gpm}$; the NaK system pressure drop was not measured. Reynolds numbers for the ranges of flow rates given were 4,400 to 21,000 for the fluoride salt and 21,000 to 100,000 for the Nak.

Limits of the over-all heat transfer coefficient based on the outside area of the center tube were 1140 and $2550 \mathrm{Btu} / \mathrm{hr}$ - ft ${ }^{2}{ }^{\circ} \mathrm{F}$. Fluoride salt film coefficients from 2000 to $8200 \mathrm{Btu} / \mathrm{hr}-\mathrm{ft}^{2}{ }^{\circ} \mathrm{F}$ were calculated.

Heat fluxes at the outer surface of the center tube from 196,000 to $484,000 \mathrm{Btu} / \mathrm{hroft}^{2}$ were obtained.

Minimum and maximum fluid velocities in the heat exchanger were 8 to $30 \mathrm{fps}$ for the fluoride salt and 1 to $6.5 \mathrm{fps}$ for the NaK. Fluoride salt temperature at the heat exchanger inlet was varied from 1200 to $1400^{\circ} \mathrm{F}$, and the corresponding outlet NaK temperature was varied from 1050 to $1250^{\circ} \mathrm{F}$. The range of the axial temperature differences through the heat exchanger was 10 to $42^{\circ} \mathrm{F}$ for the fluoride and 37 to $300^{\circ} \mathrm{F}$ for the NaK. The logarithmic mean temperature difference varied from 172 to $305^{\circ} \mathrm{F}$. 


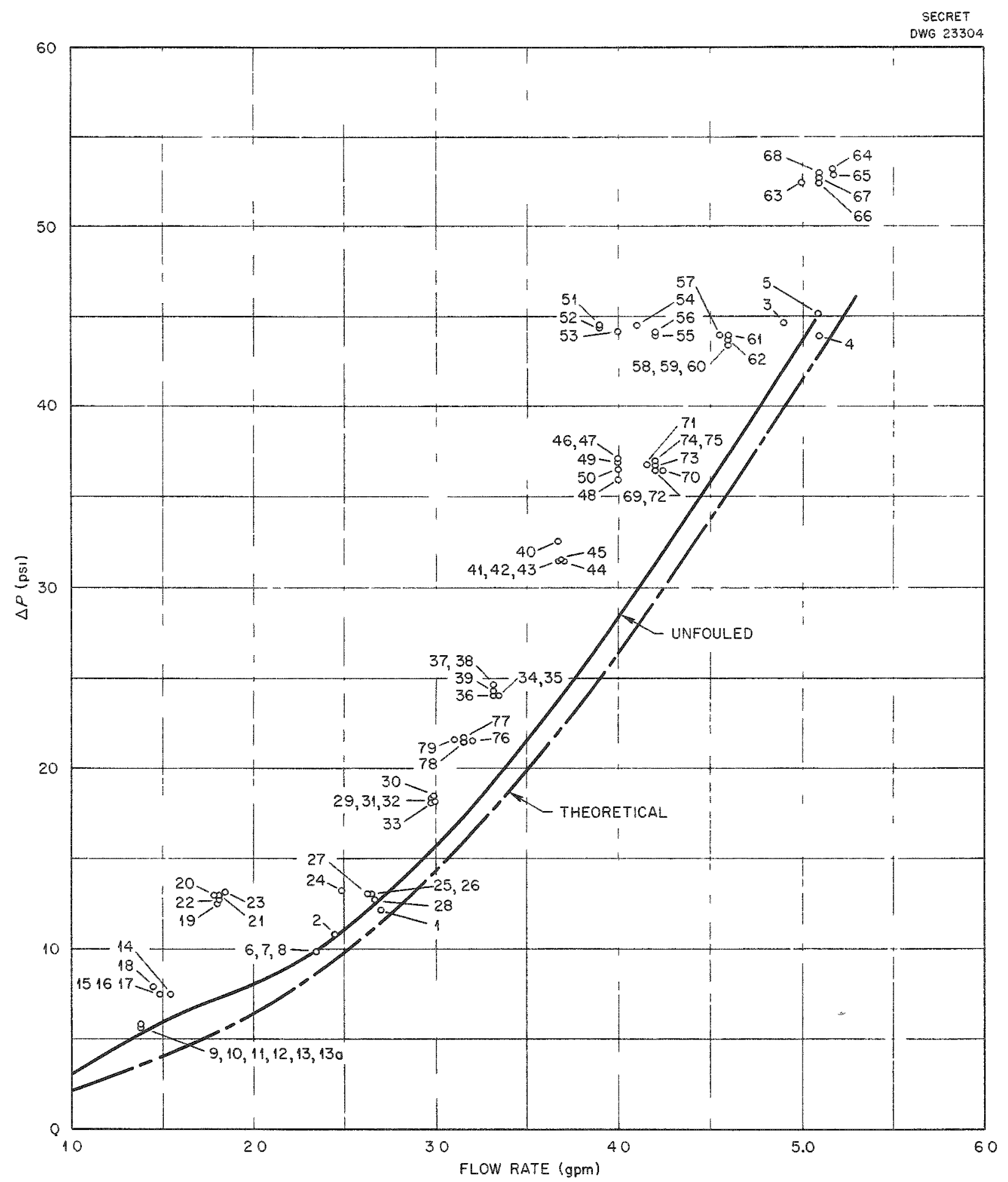

Fig. 6. Fluoride Salt System Pressure Drop vs Flow Rate for Each Run. 
TABLE 1. MEASURED AND CALCULATED RESULTS OF HEAT TRANSFER EXPERRMENTS

\begin{tabular}{|c|c|c|c|c|c|c|c|c|c|c|c|c|c|c|c|c|c|c|c|}
\hline \multirow{2}{*}{$\begin{array}{c}\text { MEASURED OR } \\
\text { CALCULATED } \\
\text { QUANTITY }\end{array}$} & \multicolumn{19}{|c|}{ DATA POINTS } \\
\hline & $(1)^{*}$ & (2) & (3) & (4) & (5) & (6) & (7) & (8) & (9) & (10) & (11) & (12) & (13) & $(13 a)^{* *}$ & (24) & (25) & (26) & (27) & (28) \\
\hline$t_{F 1}$ & 1220.5 & 1343.3 & 1323.0 & 1323.7 & 1321.5 & $131 \% .1$ & 1328.8 & 1330.8 & 1315.7 & 1332.8 & 1333.4 & 1333.7 & 1333.4 & 1334.2 & 1429.9 & 1419.3 & 1423.0 & 1420.8 & 1405.3 \\
\hline${ }^{2} N 1$ & 1154.5 & 1140.2 & 1181.9 & 1179.8 & 1164.5 & 1102.4 & 1118.3 & 1126.0 & 1057.4 & 1058.2 & 1057.1 & 1053.2 & 1054.6 & 7055.2 & 1267.4 & 1232.7 & 1228.4 & 1222.9 & 1200.7 \\
\hline${ }^{i}{ }_{w N}$ & 1151.9 & 1185.1 & 1195.0 & 1201.4 & 1203.5 & 1185.0 & 1142.9 & 1151,9 & 1083 a 4 & 1053.9 & 1053.6 & 1049.8 & 1053.5 & 1056.1 & 1253.3 & 1218.7 & 1217.6 & 1214.1 & 1214.5 \\
\hline$A_{F}$ & 10.1 & 26.8 & 14.8 & 14.6 & 15.6 & 27.2 & 29.8 & 28.3 & 37.9 & 41.3 & 41.5 & 42.3 & 41.9 & 42.4 & 25.3 & 26.9 & 27.0 & 28.4 & 27.6 \\
\hline $\mathrm{de}_{N}$ & 300.0 & 82.9 & 108.7 & 111.9 & 84.8 & 57.1 & $4 a_{\circ} 2$ & 38.5 & 81.4 & 59.8 & 49.9 & 43.0 & 37.4 & 37.0 & 150.8 & 96.6 & 71.4 & 54.2 & 46.6 \\
\hline${ }^{w_{F}}$ & 4580 & 4060 & 8110 & 8450 & 8450 & 3810 & 3810 & 3810 & 2300 & 2300 & 2300 & 2300 & 2300 & 2300 & 4050 & 4325 & 4325 & 4290 & 4340 \\
\hline$w_{N}$ & 2250 & 1170 & 1180 & 1160 & 1700 & 2235 & 2560 & 3060 & 1320 & 1960 & 2405 & 2780 & 3120 & 3120 & 635 & 1196 & 1700 & 2360 & 2850 \\
\hline$q_{F}$ & 14,320 & 33,700 & 37,200 & 38,240 & 40,850 & 32,150 & 35,200 & 33,420 & 27,000 & 29,400 & 29,600 & 30,150 & 29,900 & 30,200 & 31,780 & 36,040 & $36_{0} 200$ & 37,750 & 37,100 \\
\hline$q_{N}$ & 16,720 & 24,000 & 31,800 & 32,190 & 35,750 & 31,640 & 30,600 & 29,200 & 26,600 & 29,050 & 29,760 & 29,620 & 28,950 & 28,620 & 23,750 & 28,620 & 30,040 & 31,700 & 34,100 \\
\hline$a_{\alpha \varphi}$ & 15,520 & 28,850 & 34,500 & 35,220 & 38,300 & 31,895 & 32,900 & 31,310 & 26,800 & 29,225 & 29,680 & 29,885 & 29,425 & 29,400 & 27,765 & 32,330 & 33,120 & $34_{f} 725$ & 35,600 \\
\hline$\Delta t_{L M}$ & 172.4 & 230.2 & 184.1 & 188.6 & 189.6 & 230.0 & 220.6 & 209.9 & 279.4 & 284.0 & 280.2 & 280.9 & 276.4 & 276.9 & 218.6 & 219.9 & 216.1 & 210.3 & 214.4 \\
\hline$\theta_{0}$ & 1138 & 1582 & 2362 & 2357 & 2553 & 1750 & 1882 & 1882 & 1212 & 1300 & 1338 & 1342 & 1342 & 1340 & 1600 & 1858 & 1931 & 2080 & 2096 \\
\hline${ }^{t} F(0, A)$ & 1218.3 & 1333.4 & 1318.0 & 1318.8 & 1315.9 & 1306.7 & 1317.0 & 1319.6 & 1301.3 & 1316.7 & 1316.8 & 1376.8 & 1317.8 & 1316.5 & 1420.3 & 1410.3 & 1412.8 & 1409.9 & 1394.6 \\
\hline$t_{N}(0.4)$ & 1091.2 & 8111.5 & 1145.5 & 1142.3 & 1134.3 & 1080.6 & 1099.2 & 1110.8 & 1026.2 & 1034.8 & 1037.2 & 1032.6 & 1040.6 & 1039.8 & 1215.4 & 1200.4 & 1197.1 & 1202.0 & 1182.6 \\
\hline$t_{w F}$ & 1168.2 & 1215.5 & 1231.2 & 1236.6 & 1243.7 & 1148.5 & 1177.5 & 1184.8 & 1111.6 & 1084.7 & 1084.8 & 1081.2 & 1084.5 & $108 \% .0$ & 1282.4 & 1252.9 & 1252.4 & 1250.6 & 1251.9 \\
\hline$b_{F}$ & 4780 & 3785 & 6150 & 6620 & 8190 & 3110 & 3640 & 3590 & 2182 & 1950 & 1977 & 1961 & 1950 & 1980 & 3108 & 3165 & 3182 & 3360 & 3855 \\
\hline$b_{N}$ & 3230 & 4950 & 8830 & 7520 & 7160 & 11,700 & 9500 & 9610 & 5910 & 19,320 & $22_{g} 840$ & 21,970 & 28,800 & 22,800 & 9240 & 22,280 & 20,400 & $366_{2} 200$ & 14,100 \\
\hline${ }^{b} F(W H i s \infty n)$ & & & 5740 & 5740 & 5740 & 3055 & 3055 & 3055 & 2025 & 2025 & 2025 & 2025 & 2025 & 2025 & 3672 & 3672 & 3672 & 3672 & 3672 \\
\hline${ }^{b} N($ Wilson $)$ & & & 7700 & 7500 & 10,100 & 10,880 & 19,230 & 19,230 & 7040 & 11,570 & 15,400 & 16,120 & 16,120 & 15,880 & 4700 & 8580 & 9430 & 14,600 & 15,400 \\
\hline $\mathrm{Ni}_{F}$ & 8.12 & 6.25 & 10.30 & 11.17 & 13.80 & 5.25 & 6.15 & 6.01 & 3.72 & 3.26 & 3.31 & 3.28 & 3.26 & 3.32 & 4.78 & 4,86 & 4.86 & 5.16 & 6.01 \\
\hline $\mathrm{Ne}_{N}$ & 8.03 & 12.3 & 21.95 & 18.45 & 17.80 & 29.10 & 23.60 & 23.64 & 14.80 & 48.3 & 57.1 & 54.8 & 71.9 & 57.0 & 22.83 & 55.15 & 50.5 & 89.50 & 34.95 \\
\hline$\left.N u_{F\left(W i I_{s}\right.}\right)$ & & & 9.55 & 9.55 & 9.55 & 5.16 & 5.16 & 5,16 & 3.39 & 3.39 & 3.39 & 3.39 & 3.39 & 3.39 & 5.64 & 5.64 & 5.64 & 5.64 & 5.64 \\
\hline$\left.N u_{N(W i l s o n}\right)$ & & & 19.14 & 18.73 & 25.1 & 26.1 & 47.8 & 47.4 & 17.60 & 28.8 & 38.4 & 40.2 & 40.2 & 39.65 & 11.63 & 21.2 & 23.35 & 36.1 & 38.15 \\
\hline$R_{e_{F}}$ & 9040 & 10,260 & 19,970 & 20,300 & 20,620 & 9100 & 9300 & 9380 & 5450 & 5640 & 5640 & 5640 & 5640 & 5640 & 12,200 & 12,800 & 12,880 & 12,700 & 12,470 \\
\hline $\mathrm{Ro}_{\mathrm{Ff}}$ & 8610 & 9080 & 18,170 & 79,080 & 19,180 & 7680 & 8000 & 8090 & 4435 & 4400 & 4400 & 4390 & 4400 & 4400 & 10,580 & 10,880 & 10,980 & 10,750 & 10,780 \\
\hline $\mathrm{Re}_{N}$ & 72,700 & 38.750 & 39,100 & 38,420 & 56,300 & 72,100 & 82,600 & 101,300 & 41,600 & 61,200 & 75,900 & 87,700 & 98,400 & 98,400 & 21,580 & 40,600 & 57,700 & 80,100 & $100_{8} 200$ \\
\hline $\operatorname{Pr}_{F}$ & 6.75 & 5.13 & 5.35 & 5.35 & 5.43 & 5.55 & 5.43 & 5.35 & 5.64 & 5.36 & 5.36 & 5.36 & 5.36 & 5,36 & 3.93 & 4.07 & 4.02 & 4.08 & 4.26 \\
\hline $\mathrm{PrFf}_{\mathrm{FF}}$ & 7.09 & 5.79 & 5.87 & 5.83 & 5.85 & 6.57 & 6.31 & 6.20 & 6.97 & 6.86 & 6.86 & 6.89 & 6.86 & 6.86 & ${ }_{4.50}$ & 4.80 & 4.72 & 4.81 & $A_{w} 93$ \\
\hline $\mathrm{Pr}_{N}$ & 0.00611 & 0.00596 & 0.00596 & 0.00596 & 0.00596 & 0.00611 & 0.00611 & 0.00596 & 0.0063 & $0.00 \$ 29$ & 0.00629 & 0.90629 & 0.00629 & 0.00629 & 0.00579 & 0.00579 & 0.00578 & 0.00579 & 0.00580 \\
\hline
\end{tabular}




\section{DISCUSSION OF RESULTS}

The fluoride salt results are compared with Eq. 9 in Fig. 7 and with Eqs. 10 and 11 in Fig. 8. A least-squares analysis of the data in Fig. 7 de. termines a line to within $4 \%$ of Eq. 9, while the averaging line compared with Eqs. 10 and 11 is approximately $20 \%$ low. It appears, then, that evalu. ating the physical constants at an average of the bulk temperature and the wall temperature produces a better comparison of the results for the fluoride salt with correlating equations for ordinary fluids.

The scatter of the fluoride salt data is no doubt a reflection of the erratic nature of the heat bal. ances. Although the axial temperature differences measured were small and would result in large percentage errors for a small discrepancy in absolute value, they would tend to be consistent. The electromagnetic flowmeter readings for the NaK would likewise be consistent even if in error. The fluoride salt flow rate, on the other hand, al though measured with an accurately calibrated ventur, was quite likely the cause of the scattering. The pressure measuring technique on this venturi involved closely controlling liquid levels in the transmitters by means of floats and automatically operated solenoid gas valves.

The length-todiameter ratio of the center tube warrants some consideration here. For short tubes, where the velocity profile and boundary layer have not developed fully, the heat transfer coefficients will be greater than those for established flow. Investigations cuted by Brown and Marco ${ }^{12}$ indicate the limiting $(L / D)$ ratio for this condition to be 40 . Hoffman 13 shows entrance length, that is, number of rube diameters where the film coefficient is 1.1 times the established value, plotted as a function

12A. 1. Brown and S. M. Marco, Introduction to Heat Transfer, 2d ed., p 110, McGraw Hill, New York, 1951.

$13 \mathrm{H}$. W. Hoffman, Turbulent Forced Convection Heat Transfer in Circular Tubes Containing Molten Sodium Hydroxide, ORNL. 1370 (Oct. 3, 1952).

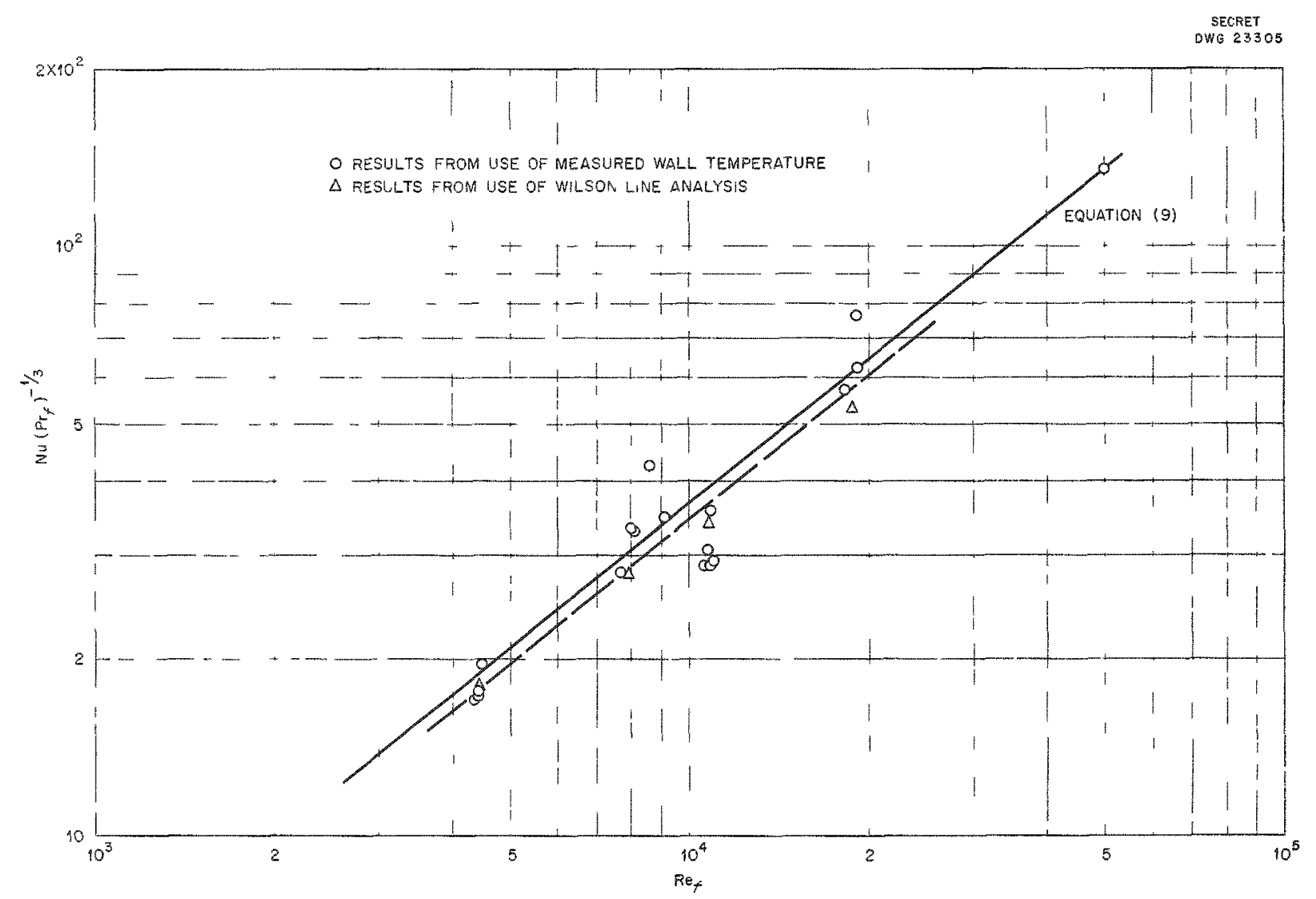

Fig. 7. Comparison of Fluoride Salt Results with the Colburn Equation. 


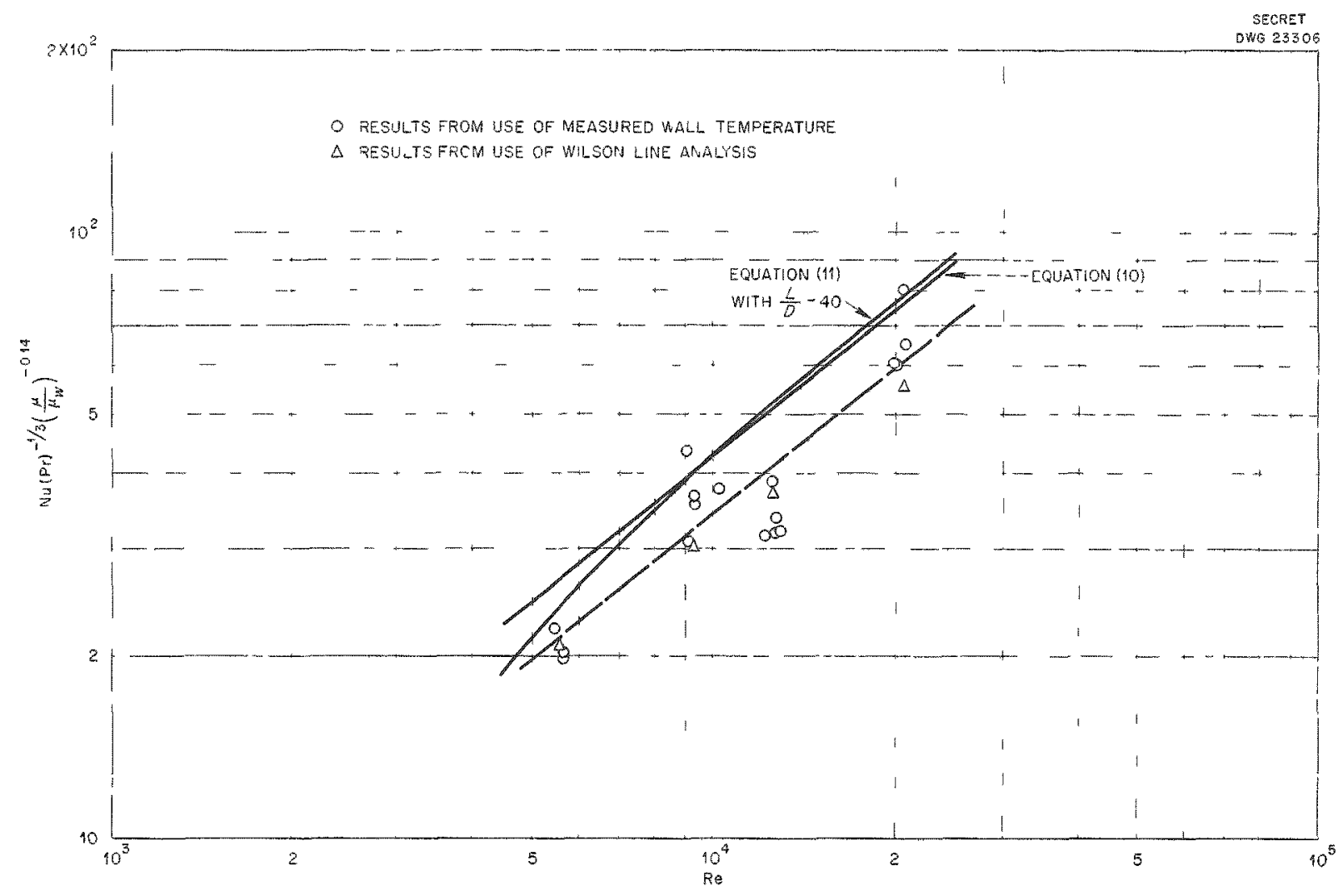

Fig. 8. Comparison of Fluoride Salt Results with the Sieder and Tate Equation and with the Hausen Equation.

of Reynolds modulus times Prandtl modulus for molten sodium hydroxide. Since the fluoride salt has a comparable Prandtl modulus, the plot should be applicable, and for the range of data of this experiment, entrance lengths up to 50 are indicated. Therefore it would be expected that the fluoride salt results would be slightly high, and it is possible that such a condition is masked by the fouling that occurred.

Another point to be discussed is that in all the correlating equations a bulk temperature was used for evaluating the results, while center-line or axis temperatures were measured in the equipment. The work of Boelter ef al., 6,7 when applied to salts, indicates the ratio $\left(t_{w}-t\right) /\left(t_{u}-t_{c}\right)$ for the fluoride salt results to be 0.92 and the ratio for the NaK to be approximately 0.58. For the fluoride salt data, therefore, the discrepancy in. volved in using an axis temperature rather than a bulk temperature is small and certainly within the accuracy of the experiment, but a large amount of uncertainty arises for the NaK data. This uncertainty is borne out in the comparison of the NaK results with Eq. 12 in Fig. 9. The relationship between axis and bulk temperature, however, has limited meaning for the NaK stream, since it was flowing in an annular space.

Failure of the measured NaK heat transfer coefficients to coincide with the theoretical equations does not necessarily reflect on the accuracy of the fluoride salt measurements, but it indicates the difficulty involved and the greater precision required in moking liquid metal heat transfer corre. lations. 


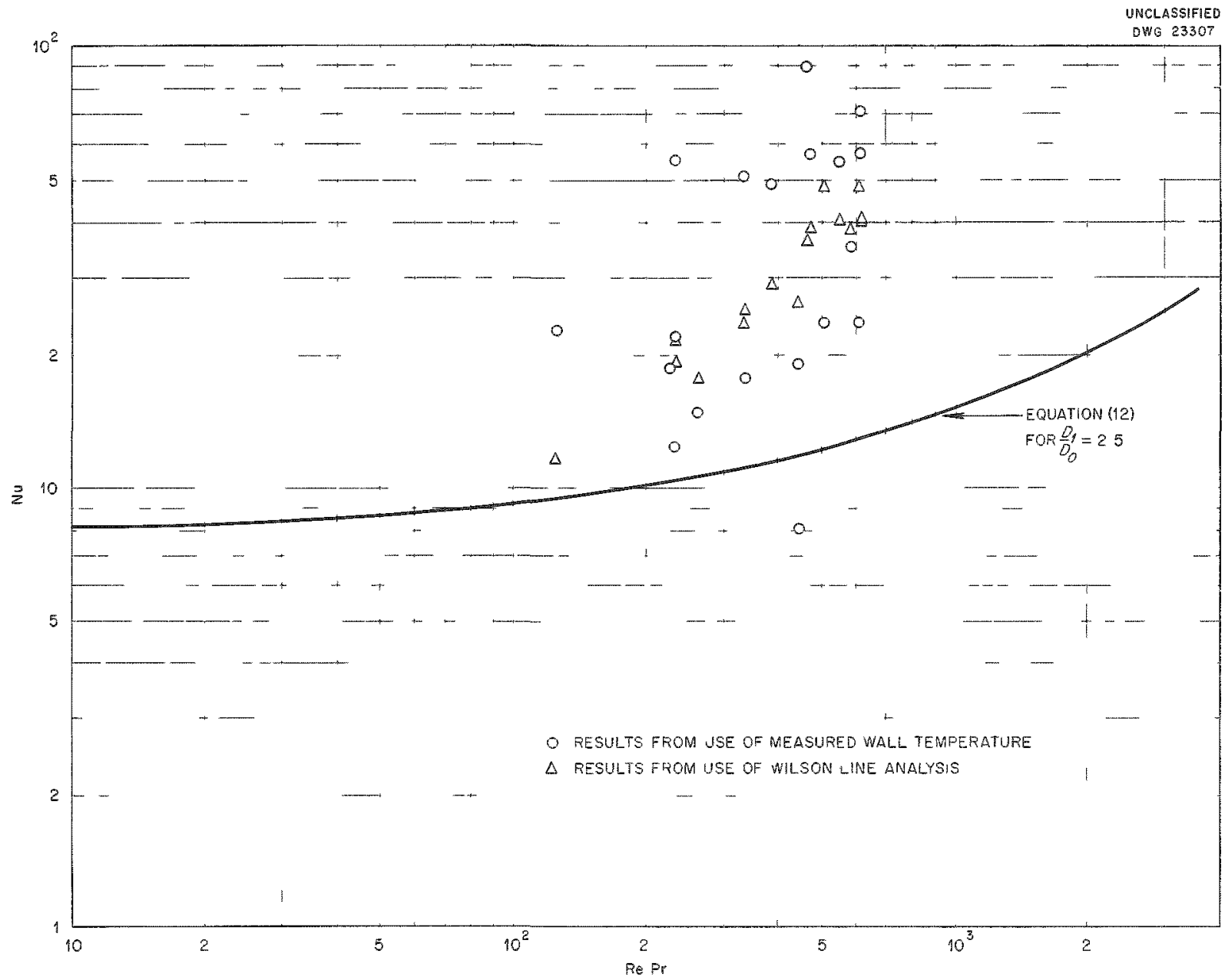

Fig. 9. Comparison of the NaK Results with the Werner, King, and Tidball Equation.

\section{CONCLUSIONS}

The fluoride salt can be considered to be an ordinary fluid with respect to heat transfer, and the equations in the literature can be used to design heat exchange equipment or to predict its performance. A similar conclusion was made by other workers at ORNL for the nonuranium-bearing fluoride salt mixture NaF-KF.LiF (11.5-42.0-46.5 mole \%). ${ }^{14}$ This would not include cases where the fluid had self-generating heat sources.

Use of Iron-bearing alloys such as type 316

\footnotetext{
14 H. W. Hoffman, Preliminary Results on Flinak Heat Transfer, ORNL CF.53-8-106 (Aug. 18, 1953).
}

stainless steel together with material not containing iron in high-temperature fluoride salt circulating systems will result in mass transfer of the iron to cold surfaces if there is turbulent flow and if there exist large temperature differences. Frictional resistance to flow will be greatly increased and heat transfer performance of equipment will be likewise impaired.

The Wilson Line approach can be used to determine heat transfer coefficients of fluoride salts at elevated tempercitures in a double-tube heat exchanger where sodium-potassium alloy is used as the cooling or heating fluid. 


\section{NOMENCLATURE}

$a$

A。

A.

An

$b$

$c_{F}$

$c_{N}$

$C$

$C_{F}$

$C_{N}$

D

$D_{i}$

D。

$D_{1}$

D

$b_{F}$

$b_{N}$

$k_{u}$

${ }_{F} \mathrm{~F}$

$k_{N}$

L

dL

$M$

$n$

$p$

gF

$q_{N}$

qov

$d$

F

$t_{N}$

$t_{c}$

${ }^{t} w$

$t_{F 1}$
Constant

Outer area of heat exchanger center fube, it $t^{2}$

Inner area of heat exchanger center tube, $f^{2}$

Transverse flow area of heat exchanger annulus, tot $^{2}$

Constont

Specific heat of the fluoride salt, Btu/lb. ${ }^{\circ} \mathrm{F}$

Specific heat of the NaK, Btu/lb. ${ }^{\circ} \mathrm{F}$

Constant

Product of specific heat and mass flow rate for the fluoride salt, Btu/hrof

Product of specific heat and mass flow rate for the NaK, Bru/hro ${ }^{\circ} \mathrm{F}$

Tube or pipe diameter in general, ft

Inner diameter of center tube, ft

Outer diameter of center tube, inner diameter of annulus, ft

Outer diameter of annulus, ft

Equivalent diameter of the annulus, or hydraulic diameter $\left(0,-D_{0}\right)$, fit

Film heat transfer coefficient for the fluoride salt, Bru/hr-ft ${ }^{2}$ of

Film heat transfer coetficient for the NaK, Bru/hroft ${ }^{2} .{ }^{\circ} \mathrm{F}$

Thermal conductivity of center-tube wall material, Btu/hr-ft- ${ }^{\circ} \mathrm{F}$

Thermal conductivity of the fluoride salt, Btu/hrofts ${ }^{\circ} \mathrm{F}$

Thermal conductivity of the NaK, Bru/hr-fto ${ }^{\circ} \mathrm{F}$

Length of heat exchanger center tube, ft

Differential length of center tube, it

Constant, equivalent to $\left(U_{0} \pi D{ }_{0}\right), B$ tu $/$ rofto ${ }^{\circ} \mathrm{F}$

Constant

Constant

Rate of heat transfer from the fluoride salt stream, Btu/hr

Rate of heat transfer to the NaK, Btu/hr

Average rate of heat transfer between the fluoride salt and NaK streams, Btu/hr

Differential rate of heat transfer, Btu/hr

Bulk temperature of stream, ${ }^{\circ} \mathrm{F}$

Bulk temperature of fluoride, of

Bulk temperature of Nak, of

Axis or center-line temperature of stream, ${ }^{\circ} \mathrm{F}$

Temperature of tube wall surface, of

Inlef fluoride axis temperature to heat exchanger, of 


\begin{tabular}{|c|c|}
\hline$t_{F 2}$ & Outlet fluoride axis temperature from heat exchanger, of \\
\hline${ }^{t} N$ & Outlet NaK axis pemperature from heat exchanger, of \\
\hline${ }^{t}{ }_{N 2}$ & Inlet Nak axis temperature to heat exchanger, of \\
\hline${ }^{t} F(0.4)$ & Fluoride axis temperature ot $0.4 L,{ }^{\circ} \mathrm{F}$ \\
\hline${ }^{t} N(0.4)$ & NaK axis temperature at $0.4 L,{ }^{\circ} \mathrm{F}$ \\
\hline$t_{w F}$ & Center tube surface temperature on flueride salt side at $0.4 \mathrm{~L}$, ${ }^{\circ} \mathrm{F}$ \\
\hline$t_{w N}$ & Center tube surface temperature on NaK side at $0.4 L$, of \\
\hline${ }^{t} F f$ & Fictive fluoride salt film temperature ot $0.4 L,\left[\frac{{ }^{t} F(0.4)+{ }^{t} u F}{2}\right],{ }^{2} F$ \\
\hline$d t_{F}$ & Differential fluoride salt bulk temperature, of \\
\hline$d t$ & Differential Nak bulk temperature, ${ }^{\circ} \mathrm{F}$ \\
\hline$U_{0}$ & $\begin{array}{l}\text { Over-all heat transfer coefficient based on outer area of heat ex- } \\
\text { changer center tube, Bru/hr-ft }{ }^{2} \text { of }\end{array}$ \\
\hline$U_{00}$ & 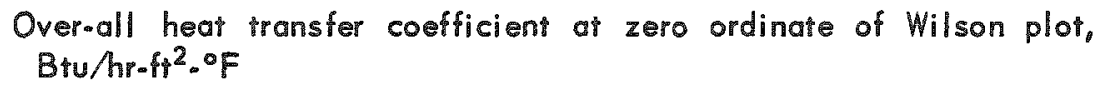 \\
\hline$v$ & Meon flow velocity, ft hr \\
\hline$\imath^{\prime} N$ & Mean NaK velocity in annulus, fps \\
\hline$u_{F}$ & Mass flow rate of fluoride salt, $\mathrm{lb} / \mathrm{hr}$ \\
\hline$u^{\prime} N$ & Mass flow rate of $\mathrm{NaK}, \mathrm{lb} / \mathrm{hr}$ \\
\hline$\Delta t$ & $\begin{array}{l}\text { Temperature difference of fluoride salt and NaK at any cross section } \\
\text { of heat exchanger, of }\end{array}$ \\
\hline$\Delta t_{F}$ & Temperature drop of fluoride salt through the exchanger, of \\
\hline$\Delta t_{N}$ & Temperature rise of NaK through the exchanger, of \\
\hline$\Delta t_{1}$ & $\begin{array}{l}\text { Temperature difference of fluoride solt and Nak at hot end of ex- } \\
\text { changer, of }\end{array}$ \\
\hline$\Delta t_{2}$ & $\begin{array}{l}\text { Temperature difference of fluoride salt and NaK at cold end of ex- } \\
\text { changer, of }\end{array}$ \\
\hline$\Delta t_{\mathrm{LM}}$ & Logarithmic mean of $\Delta t_{1}$ and $\Delta t_{2}{ }^{\circ} \mathrm{F}$ \\
\hline$B$ & Constant $\left(\frac{1}{C_{F}}+\frac{1}{C_{N}}\right), \mathrm{hr} \cdot{ }^{\circ} \mathrm{F} / \mathrm{Bru}$ \\
\hline$\pi$ & Constant, 3.1416 \\
\hline$\rho$ & Mass density evaluated at bulk temperature, $\mathrm{Ib} / \mathrm{ft}^{3}$ \\
\hline$\rho_{F}$ & Mass density of fluoride salt evaluated at axis temperature, $\mathrm{Ib} / \mathrm{ft}^{3}$ \\
\hline$\rho_{N}$ & Mass density of NaK evaluated at axis temperature, $1 \mathrm{~b} / \mathrm{ft}^{3}$ \\
\hline$\mu$ & Absolute viscosity evaluated at bulk temperature, $\mathrm{lb} / \mathrm{hr}$-ft \\
\hline$\mu_{F}$ & $\begin{array}{l}\text { Absolute viscosity of fluoride salt evaluated at axis femperature, } \\
\text { Ib/hr-fi }\end{array}$ \\
\hline$\mu_{N}$ & Absolute viscosity of Nak evaluated at axis temperature, $\mathrm{lb} / \mathrm{hr}$-ft \\
\hline$\mu_{F j}$ & $\begin{array}{l}\text { Absolute viscosity of fluoride salt evoluated at film temperature, } \\
\text { lb/hr-ft }\end{array}$ \\
\hline
\end{tabular}


$\mu_{u}$ Absolute viscosity evaluated at tube surface temperature, $\mathrm{lb} / \mathrm{hr}$ ft

Nu $\frac{b D}{k}, \quad$ Nusselt modulus (tube)

Nu $\quad \frac{b_{F} D_{i}}{k_{F}}, \quad$ Nusselt modulus for fluoride salt

$N u_{N} \frac{b_{N} D_{e}}{k_{N}}, \quad$ Nusselt modulus for NaK

Nuan $\frac{b D}{k}, \quad$ Nusselt modulus for an annular passage

$\operatorname{Re} \frac{\rho D v^{\prime}}{\mu}, \quad$ Reynolds modulus

$\operatorname{Re}_{F} \quad \frac{\rho_{F} D_{i} v_{F}}{\mu_{F}}$, Reynolds modulus for fluoride salt

$\operatorname{Re}_{F f} \frac{{ }^{O} F{ }_{i}^{l^{\prime} F}}{\mu_{F f}}$, Reynolds modulus for fluoride salt with viscosity evaluated at $t_{F f}$

$\operatorname{Re}_{V} \frac{\rho_{N} D e^{l^{\prime \prime} N}}{\mu_{N}}$, Reynolds modulus for NaK

$\operatorname{Pr} \quad \frac{C_{p}^{\mu}}{k}, \quad$ Prandil modulus

$\operatorname{Pr}_{F} \frac{C_{F} \mu_{F}}{k_{F}}$, Prandil modulus for fluoride salt

$\operatorname{Pr}_{F f} \frac{C_{F} \mu_{F f}}{k_{F}}$, Prandil modulus for fluoride salt with viscosity evaluated at $t_{F f}$

$\mathrm{Pr}_{N} \frac{C_{N} \mu_{N}}{k_{N}}$, Prandil modulus for NaK 


\section{EQUATION FOR INTERMEDIATE AXIAL STREAM TEMPERATURE WITH LOGARITHMIC DISTRIBUTION}

To evaluate the temperature difference across the film at the point in the heat ex. changer where the center wall temperature was measured, it was necessary to determine the stream temperature at this position.
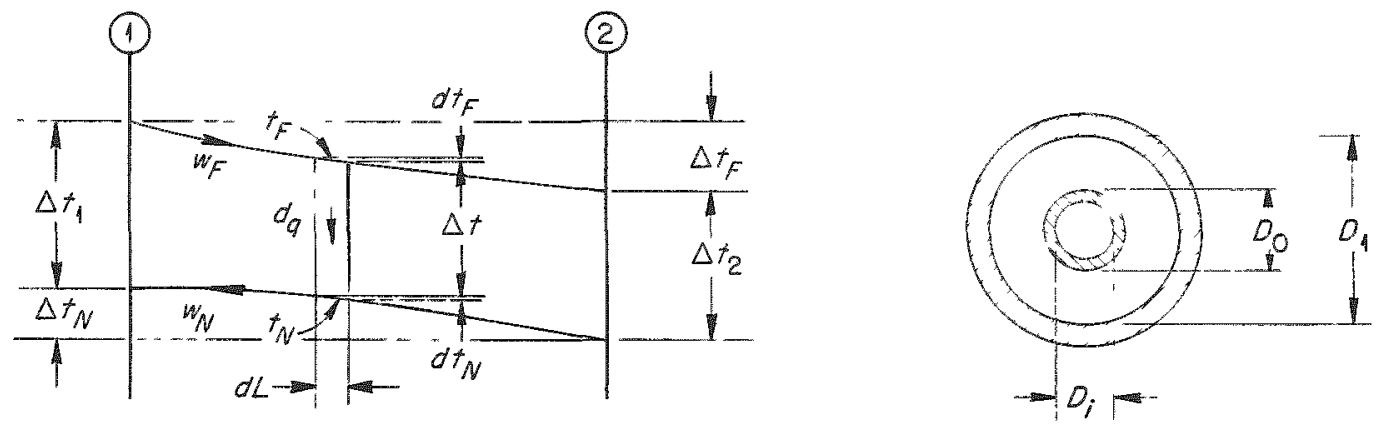

By assuming a constant over-all heat transfer coefficient with steady-state operation and neglecting heat losses, the basic equation for this configuration is

$$
d_{q}=-w_{F} c_{F}^{d t}=-w_{N}{ }_{N} d t=v_{o} D_{o} d L \Delta t \text {. }
$$

For the fluoride stream,

$$
d t_{F}=-\frac{U_{0} \pi D_{0} d L \Delta t}{w_{F} c_{F}} .
$$

To integrate Eq. 2, $\Delta t$ must be written as a function of $L$. This is done in the usual derivation of the logarithmic mean temperature difference found in the literature; therefore,

$$
\Delta t=\Delta t_{1} e^{-\beta M L}
$$

The constants have been grouped and simplified as follows:

$$
\begin{gathered}
w_{F} c_{F}=C_{F} \text { and } w_{N}{ }^{c}=C_{N}, \\
\beta=\frac{1}{C_{F}}-\frac{1}{C_{N}}, \\
M=U_{0} \pi D_{0} .
\end{gathered}
$$

Substituting Eq. 3 in Eq. 2 gives

$$
d t_{F}=-\frac{M \Delta t_{1}}{C_{F}} e^{-\beta M L} d L .
$$


Integrating and considering the boundary condition, when $L=0$ and $t_{F}=t_{F 1}$, Eq. 4 becomes

$$
t_{F}=t_{F 1}-\frac{\Delta t_{1}}{\beta C_{F}}\left(1-e^{-B M L}\right) .
$$

In like manner, for the NaK stream,

$$
{ }^{t_{N}}=t_{N 1}-\frac{\Lambda t_{1}}{\beta C_{N}}\left(1-e^{-\beta M L}\right) .
$$

Equations 5 and 6 can be written for the position where the wall temperatures were measured, at $0.4 L$, and also changed to involve only the measured temperature quantities. By noting that

$$
\beta C_{F}=1-\frac{\Delta t_{N}}{\Delta t_{F}} \text { and } \beta C_{N}=\frac{1-\frac{\Delta t_{N}}{\Delta t_{F}}}{\frac{\Delta t_{N}}{\Delta t_{F}}}
$$

and by using Eq. 5,

$$
{ }^{t_{F(0.4)}}=t_{F 1}-\frac{\Delta t_{1}}{1-\frac{\Delta t_{N}}{\Delta t_{F}}}\left[1-\left(\frac{\Delta t_{2}}{\Delta t_{1}}\right)^{0.4}\right] ;
$$

and by using Eq. 6,

$$
{ }^{t} N\left(0.4_{1}\right)=t_{N 1}-\frac{\Delta t_{1} \frac{\Delta t_{N}}{\Delta t_{F}}}{1-\frac{\Delta t_{N}}{\Delta t_{F}}}\left[1-\left(\frac{\Delta t_{2}}{\Delta t_{1}}\right)^{0.4}\right] .
$$




\section{APPENDIX 2}

\section{DERIVATION OF EQUATIONS FOR WILSON LINE ANALYSIS}

In a liquid-to-liquid heat exchanger where neither fluid changes phase, if one of the fluid velocities is held constant and the other is varied over a range of settings in turbu. lent flow, the film coefficient of the fluid at constant velocity can be determined by a graphical method called the Wilson Line or Wilson plot.

When the mean temperature of the constant velocity fluid does not vary appreciably, the film coefficient will be essentially constant. The film coefficient of the other fluid, where there are not large changes of physical properties with temperature, is a function solely of the velocity.

The graphical method was used in this experiment to obtain coefficients of the fluoride salt and thus separate the overall heat transfer coefficient to obtain a NaK film coefficient. If the series resistance concept is used, the over-all coefficient is related to the film coefficients as follows:

$$
\frac{1}{U_{0}}=\frac{D_{0}}{b_{F} D_{i}}+\frac{D_{0} \ln \frac{D_{0}}{D_{i}}}{2 k_{w}}+\frac{1}{b_{N}} .
$$

Equation 1 neglects the resistance of any foreign deposits on the heat exchanger walls, but such deposits would enter the equation in a term similar to that for the wall resis. tance, that is, the middle term in the right side of the expression.

The equation relating the NaK coefficient (Eq. 12 in the text) reduces to

$$
b_{N}=a+b v_{N}^{0.8} \text {. }
$$

For $D_{0}=0.329 \mathrm{in}_{\circ}, D_{i}=0.269 \mathrm{in}_{\circ}$, and $k_{w}=34.8 \mathrm{Bru} / \mathrm{hr}-\mathrm{ft}_{-}^{\circ} \mathrm{F}, \mathrm{Eq} .1$ above becomes

$$
\frac{1}{U_{o}}=\frac{1.222}{b_{F}}+0.0000788+\frac{1}{a+b v_{N}^{0.8}} .
$$

Sinee the NaK velocity is the only significant variable, a plot of $1 / U_{0}$ vs $1 /\left(a+b v_{N}{ }^{0.8}\right)$ should produce a straight line. For such a plot, the constants $a$ and $b$ must be known. They could be taken from Eq. 12 of the text; instead, $V / U_{0}$ was plotted against $V / v_{N}{ }^{0.8}$, as is usually done with ordinary fluids. The data of the experiment proved to be fairly well correlated by straight lines.

Inspection of Eq. 3 above shows that when the term involving $v_{N}{ }^{0.8}$ approaches zero, or when the Wilson Line is extrapolated to the zero ordinate, it is possible to write for all the intercepis

$$
\frac{1}{U_{00}}=\frac{1.222}{b_{F}}+0.0000788 .
$$

From Eq. 4 it is possible to solve for the fluoride salt film coefficient, that is,

$$
b_{F}=\frac{1.222}{\frac{1}{U_{D 0}}-0.0000788} .
$$


Since the fluoride salt film coefficient is essentially constant along any of the lines, it is possible to separate the NaK film coefficient from any of the over-all coefficients. Substitution in Eq. 1 above gives

$$
b_{N}=\frac{1}{\frac{1}{U_{0}}-\frac{1.222}{b_{F}}-0.0000788}=\frac{1}{\frac{1}{U_{0}}-\frac{1}{U_{00}}} .
$$

\section{APPENDIX 3}

\section{PHYSICAL PROPERTIES OF THE FLUORIDE SALT NaF.ZIF .UF $(50-46.4$ mole \%) AND OF SODIUM.POTASSIUM EUTECTIC ALLOY}

The physical properties of the fluoride salt were taken from the third edition charts of the ANP Physical Properties Group' and are represented as a function of temperature in Fig. 10. The charts are revised periodically as new data become avallable. The NaK properfies given in Fig. 11 were taken from the second edition of the Liquid Metals Handbook. ${ }^{15}$

\footnotetext{
${ }^{15}$ R. N. Lyon (ed.), Liquid-Merals Handbook, NAV EXOS P.733 (Rev.) (June 1952).
} 


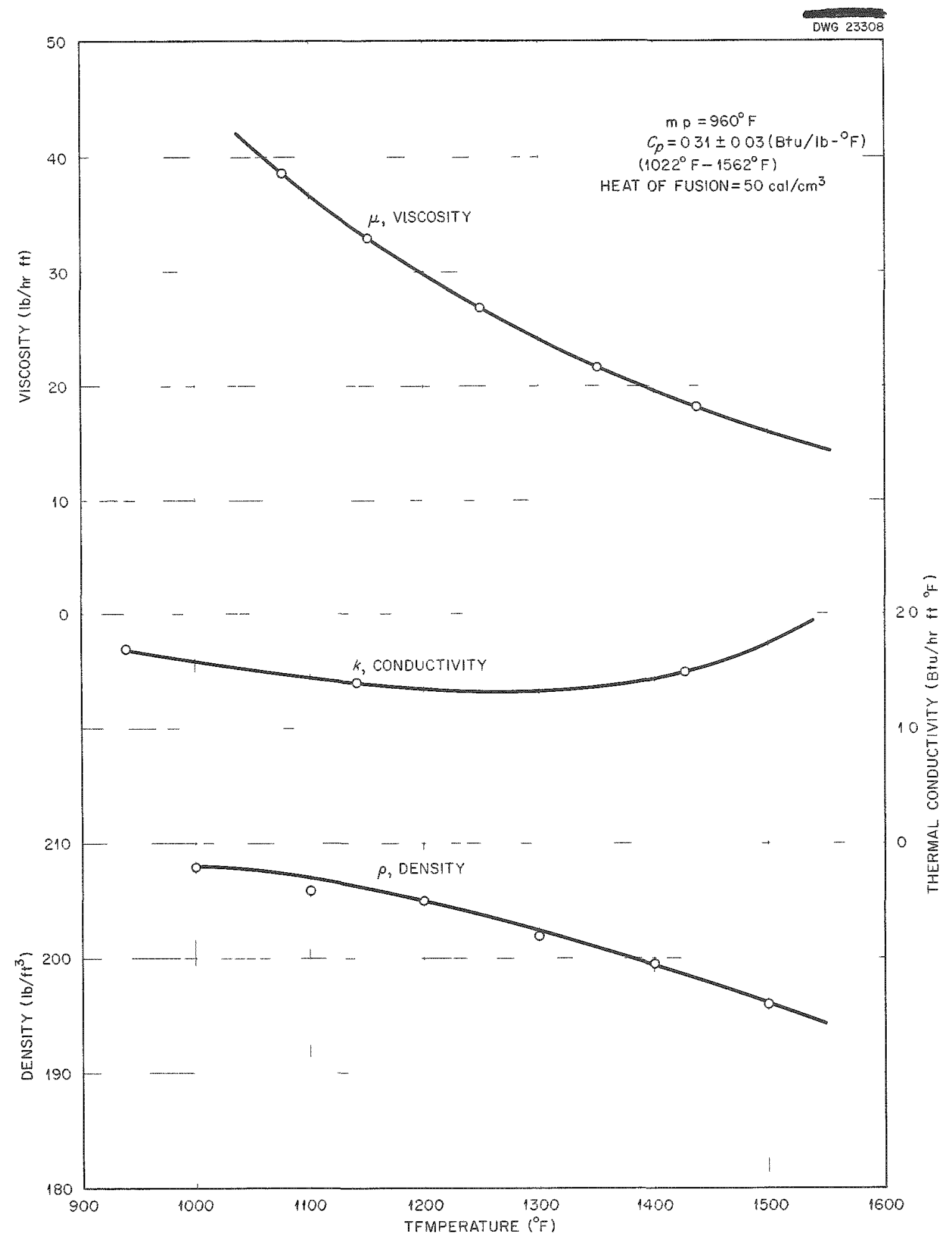

Fig. 10. Physical Properties of the Fluoride Salt vs Temperature. 


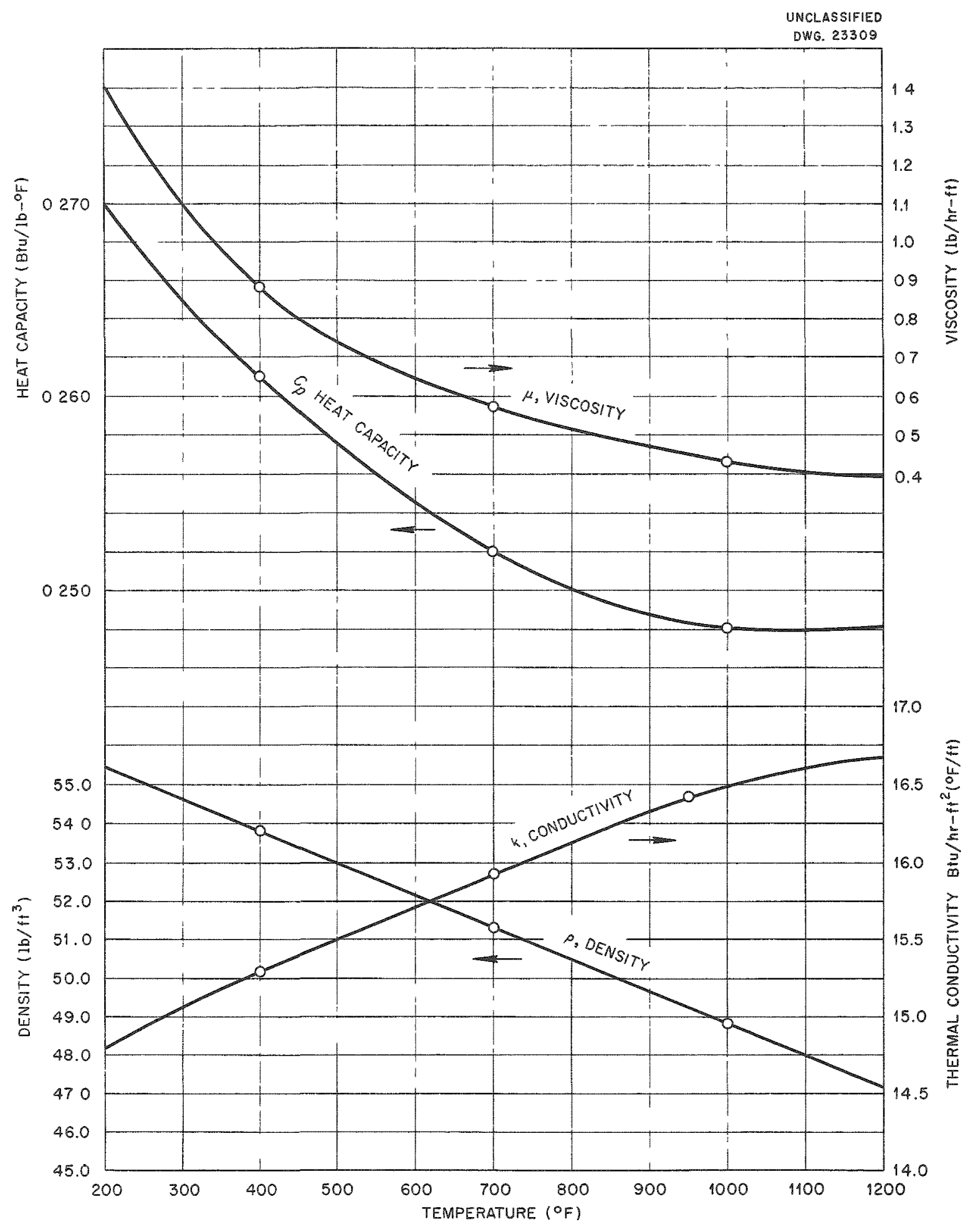

Fig. 11. Physical Properties of $\operatorname{NaK}(56$ wt\% $\mathbb{N a}-44$ wt\% K) vs Temperature. 
APPENDIX 4

\section{SAMPLE CALCULATION OF DATA POINT 4}

Experimental Data

Heat Balance

$$
\begin{aligned}
& t_{F 1}=1323.7^{\circ} \mathrm{F} \\
& t_{F 2}=1309.1^{\circ} \mathrm{F} \\
& { }^{t_{N 1}}=1179.8^{\circ} \mathrm{F} \\
& t_{N 2}=1067.9^{\circ} \mathrm{F} \\
& w_{F}=8450 \mathrm{lb} / \mathrm{hr} \\
& { }_{N}=1160 \mathrm{lb} / \mathrm{hr} \\
& { }_{u N}=1201.4^{\circ} \mathrm{F}
\end{aligned}
$$

$$
\begin{aligned}
q_{F} & =u_{F} c_{F}\left(t_{F 1}-t_{F 2}\right) \\
& =(8450)(0.31)(14.6)=38,240 \mathrm{Btu} / \mathrm{hr} \\
q_{N} & =w_{N} c_{N}\left(t_{N 1}-t_{N 2}\right) \\
& =(1160)(0.248)(111.9)=32,190 \mathrm{Btu} / \mathrm{hr}
\end{aligned}
$$

(Heat loss less than $1 \%$ and therefore neglected)

$$
\begin{gathered}
\frac{q_{F}-q_{N}}{q_{F}}=\frac{6,050}{38,240}=16 \% \\
q_{a v}=35,220 \mathrm{Biu} / \mathrm{hr}
\end{gathered}
$$

Over-all Heat Transfer Coefficient

$$
\begin{aligned}
& U_{0}=\frac{q_{a v}}{A_{0} \Delta t_{L M}} \\
& \Delta t_{L M}=\frac{\left(t_{F 1}-t_{N 1}\right)-\left(t_{F 2}-t_{N 2}\right)}{\ln \frac{t_{F 1}-t_{N 1}}{t_{F 2}-t_{N 2}}}=\frac{143.9-241.2}{\ln \frac{143.9}{241.2}}=188.6^{\circ} \mathrm{F} \\
& U_{o}=\frac{35,220}{0.0792(188.6)}=2357 \mathrm{Bru} / \mathrm{hr}-\mathrm{ft}^{2}{ }_{\circ}{ }^{\circ} \mathrm{F}
\end{aligned}
$$

Wall Temperatures

$$
\begin{aligned}
t_{w N} & =1201.4 \text { (measured) } \\
t_{w F} & =t_{w N}+\frac{q_{a v} \ln \frac{D_{o}}{D_{2}}}{2 \pi k w^{L}} \\
& =1201.4+\frac{35,220 \ln \frac{0.329}{0.269}}{2 \pi(34.8)(0.922)}=1236.6^{\circ} \mathrm{F}
\end{aligned}
$$


Stream Temperatures

$$
\begin{aligned}
& t_{F(0.4)}=t_{F 1}-\frac{\Delta t_{1}}{1-\frac{\Delta t_{N}}{\Delta t_{F}}}\left[1-\left(\frac{\Delta t_{2}}{\Delta t_{1}}\right)^{0.4}\right] \\
& =1323.7-\frac{143.9}{(1-7.66)}[1-1.229]=1318.8^{\circ} \mathrm{F} \\
& { }^{t} N(0.4)=t_{N 1}-\frac{\Delta t_{1} \frac{\Delta t_{N}}{\Delta t_{F}}}{1-\frac{\Delta t_{N}}{\Delta t_{F}}}\left[1-\left(\frac{\Delta t_{2}}{\Delta t_{1}}\right)^{0.4}\right] \\
& =1179.8-(4.9)(7.66)=1142.3^{\circ} \mathrm{F}
\end{aligned}
$$

Film Coefficients

$$
\begin{aligned}
b_{F} & =\frac{q_{a v}}{A_{i}\left[t_{F(0.4)}-t_{u F}\right]} \\
& =\frac{35,220}{0.0647(82.2)}=6620 \mathrm{Bru} / \mathrm{hr}-\mathrm{ft}^{2}{ }^{\circ} \mathrm{F} \\
b_{N} & =\frac{q_{a v}}{A_{0}\left[t_{u N}-t_{N(0.4)}\right]} \\
& =\frac{35,220}{0.0792(59.1)}=7520 \mathrm{Bru} / \mathrm{hr}-\mathrm{ft}^{2}-\circ \mathrm{F}
\end{aligned}
$$

Wilson Line

$$
\begin{gathered}
\frac{1}{u_{o}}=\frac{1}{2357}=0.000425 \mathrm{hr}-\mathrm{ft}^{2}{ }_{-}{ }^{\circ} \mathrm{F} / \mathrm{Btu} \\
v_{N}=\frac{u_{N}}{\rho_{N} A_{a n}}=\frac{1160(144)}{(48.2)(0.448)(3600)}=2.15 \mathrm{ft} / \mathrm{sec} \\
\frac{1}{v_{N}^{0.8}}=\frac{1}{1.84}=0.542
\end{gathered}
$$

From Fig. $5, \frac{1}{U_{o 0}}$ at $\frac{1}{v_{N}^{0.8}}=0$ for this line is 0.000292 .

$$
b_{F}=\frac{1.222}{\frac{1}{U_{00}}-0.0000788}=5740 \mathrm{Bru} / \mathrm{hr}^{\prime}-\mathrm{ft}^{2} \mathrm{o} . \mathrm{F}
$$




$$
b_{N}=\frac{1}{\frac{1}{U_{0}}-\frac{1.222}{b_{F}}-0.0000788}=7500 \mathrm{Btu} / \mathrm{hroft}^{2}{ }^{\circ} \mathrm{OF}_{\mathrm{F}}
$$

\section{Dimensionless Moduli}

Ar $t_{F f}=1278^{\circ} \mathrm{F}$,

$$
\begin{aligned}
& c_{F}=0.31 \mathrm{Biu} / \mathrm{lb}=\circ \mathrm{F} \\
& \mu_{F f}=25.2 \mathrm{lb} / \mathrm{hr}-\mathrm{ft} \\
& k_{F}=1.34 \mathrm{Biu} / \mathrm{hr}-\mathrm{ft}-\circ \mathrm{F} \\
& \mathrm{Nu}_{F}=\frac{h_{F} D_{i}}{k_{F}}=\frac{6620(0.269)}{1.34(12)}=11.17 \\
& \operatorname{Re}_{F f}=\frac{4 w_{F}}{\pi \mu_{F f} D_{i}}=\frac{4(8450)(12)}{\pi(25.2)(0.269)}=19,080 \\
& \operatorname{Pr}_{F f}=\frac{c_{F} \mu_{F f}}{k_{F}}=\frac{0.31(25.2)}{1.34}=5.83,\left(\operatorname{Pr}_{F}\right)^{1 / 3}=1.801 \\
& \left.\mathrm{Nu} \operatorname{Pr}_{F f}\right)^{-1 / 3}=6.2
\end{aligned}
$$

At $t_{F(0.4)}=1319^{\circ} \mathrm{F}$ 。

$$
\begin{aligned}
& c_{F}=0.31 \mathrm{Btu} / \mathrm{lb}-{ }^{\circ} \mathrm{F} \\
& \mu_{F}=23.1 \mathrm{lb} / \mathrm{hr}-\mathrm{ft} \\
& k_{F}=1.34 \mathrm{Bru} / \mathrm{hr}-\mathrm{ftr}^{\circ}{ }^{\circ} \mathrm{F}
\end{aligned}
$$

Ar $t_{w F}=1237^{\circ} \mathrm{F}$,

$$
\begin{aligned}
& \mu_{w F}=27.5 \mathrm{lb} / \mathrm{hr}-\mathrm{ft} \\
& \mathrm{Nu}_{F}=\frac{b_{F} D_{i}}{k_{F}}=\frac{6620(0.269)}{1.34(12)}=11.17 \\
& \operatorname{Re}_{F}=\frac{4 w_{F}}{\pi \mu_{F} D_{i}}=\frac{4(8450)(12)}{\pi(23.1)(0.269)}=20,800 \\
& \operatorname{Pr}_{F}=\frac{c_{F} \mu_{F}}{k_{F}}=\frac{0.31(23.1)}{1.34}=5.35
\end{aligned}
$$




$$
\begin{aligned}
& \left(\operatorname{Pr}_{F}\right)^{1 / 3}=1.75 \\
& \left(\frac{\mu}{\mu_{w}}\right)_{F}=\frac{23.1}{27.5}=0.84 \\
& \left(\frac{\mu}{\mu_{w}}\right)_{F}^{0.14}=0.976 \\
& \operatorname{Nu}_{F}\left(\operatorname{Pr}_{F}\right)^{-1 / 3}\left(\frac{\mu}{\mu_{u}}\right)_{F}^{-0.14}=6.48
\end{aligned}
$$

$$
\begin{aligned}
& \text { At } t_{N(0.4)}=1142^{\circ} \mathrm{F} \text {, } \\
& \varepsilon_{N}=0.248 \mathrm{Bru} / \mathrm{lb} \cdot{ }^{\circ} \mathrm{F} \\
& \rho_{N}=47.7 \mathrm{lb} / \mathrm{ft}^{3} \\
& \mu_{N}=0.4 \mathrm{lb} / \mathrm{hr}-\mathrm{ft} \\
& k_{N}=16.65 \mathrm{Bru} / \mathrm{hr}=\mathrm{ftr}_{\mathrm{O}}^{\circ} \mathrm{F} \\
& N u_{N}=\frac{b_{N} D_{e}}{k_{N}}=\frac{7520(0.495)}{16.65(12)}=18.45 \\
& \operatorname{Re}_{N}=\frac{\rho_{N} e_{e} V_{N}}{\mu_{N}}=\frac{47.7(0.495)(2.15)(3600)}{(12)(0.4)}=38,420 \\
& \operatorname{Pr}_{N}=\frac{c_{N} \mu_{N}}{{ }_{k}}=\frac{0.248(0.4)}{16.65}=0.00596 \\
& \operatorname{Re}_{N} \times \mathrm{Pr}_{N}=229
\end{aligned}
$$

